\title{
The Impacts of the Coronavirus on the Economy of the United States
}

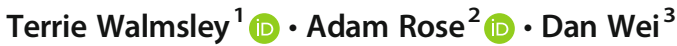

Received: 5 September 2020 / Accepted: 6 November 2020/ Published online: 10 December 2020

(C) Springer Nature Switzerland AG 2020

\begin{abstract}
We present a formal analysis of the macroeconomic impacts of the COVID-19 pandemic in the U.S., China and the rest of the world. Given the uncertainty regarding the severity and time-path of the infections and related conditions, we examine three scenarios, ranging from a relatively moderate event to a disaster. The study considers a comprehensive list of causal factors affecting the impacts, including: mandatory closures and the gradual re-opening process; decline in workforce due to morbidity, mortality and avoidance behavior; increased demand for health care; decreased demand for public transportation and leisure activities; potential resilience through telework; increased demand for communication services; and increased pent-up demand. We apply a computable general equilibrium (CGE) model, a state-of-the-art economy-wide modeling technique. It traces the broader economic ramifications of individual responses of producers and consumers through supply chains both within and across countries. We project that the net U.S. GDP losses from COVID-19 would range from $\$ 3.2$ trillion (14.8\%) to $\$ 4.8$ trillion $(23.0 \%)$ in a 2-year period for the three scenarios. U.S. impacts are estimated to be higher than those for China and the ROW in percentage terms. The major factor affecting the results in all three scenarios is the combination of Mandatory Closures and Partial Reopenings of businesses. These alone would have resulted in a $22.3 \%$ to $60.6 \%$ decrease in U.S. GDP across the scenarios. Pent-up Demand, generated from the inability to spend during the Closures/Reopenings, is the second most influential factor, significantly offsetting the overall negative impacts.
\end{abstract}

Keywords COVID-19 · Macroeconomic impacts · Telework $\cdot$ Healthcare costs $\cdot$ Avoidance behavior $\cdot$ Pent-up demand

JEL Classifications E65 $\cdot$ I15 $\cdot$ C68

This article is part of the Topical Collection on Economics of COVID-19

Adam Rose

adam.rose@usc.edu

Extended author information available on the last page of the article 


\section{Introduction}

COVID-19 is already having far-ranging economic consequences, and the end is not yet in sight. This paper summarizes a formal analysis of the macroeconomic impacts of the pandemic in the U.S., China and the rest of the world. Given the uncertainty regarding the severity and time-path of the infections and related conditions, we examine three scenarios, ranging from a relatively moderate event to a disaster. Specifically, the study considers a comprehensive list of causal factors affecting the impacts, including: mandatory closures and the gradual re-opening process; decline in workforce due to morbidity, mortality and avoidance behavior; increased demand for health care; decreased demand for public transportation and leisure activities; potential resilience through telework; increased demand for communication services; and increased pent-up demand. Note, however, that we have not included the impact of countervailing policies, such as the CARES Act, nor the value of lives lost.

The analysis is based on the application of a computable general equilibrium (CGE) model, a stateof-the-art economy-wide modeling technique. CGE is defined as a multi-market model of the behavioral responses of producers and consumers to changing prices, regulations, and other conditions in the workings of interconnected markets, subject to basic resource constraints. CGE models have the advantage of characterizing the economy as a set of interconnected supply chains. These models have been applied successfully to examine economic impacts of health threats, such as influenza pandemics (see, e.g., Dixon et al. 2010, 2020; Prager et al. 2017; Walmsley et al. 2020). In particular, we use the ImpactECON Supply-Chain Model (Walmsley and Minor 2016, 2020a). This Model is adapted from one of the most widely-used CGE models, GTAP (Hertel and Tsigas 1997; Corong et al. 2017), and has the extended capability for examining supply-chain impacts linked to economic activity and policies in the rest of the world.

In performing the analysis, we utilize the assumptions, variables and parameters presented in detail in the various Appendices. The assumptions are invoked primarily to keep the analysis manageable. Sensitivity tests have been performed on some of the major assumptions and parameters to make sure the results presented are robust. Still, we note that the combination of assumptions is such that the results presented should be considered upper-bound estimates. To summarize, the net U.S. Real GDP losses from COVID-19 are estimated to range from $\$ 3.2$ trillion (14.8\%) to $\$ 4.8$ trillion (23.0\%) in a 2year period for the three scenarios. U.S. impacts are estimated to be higher than those for China and the ROW in percentage terms. The major factor affecting the results in all three scenarios is the combination of Mandatory Closures and Partial Reopenings of businesses. These alone would have resulted in a $22.3 \%$ to $60.6 \%$ decrease in the U.S. GDP across the scenarios. Pent-up Demand, generated from the inability to spend during the Mandatory Closures and Partial Reopenings, is the second most influential factor and offsets the negative impacts of Closures/Reopenings by about $30 \%$ for all three regions in the moderate and declining scenario and up to $60 \%$ to $85 \%$ in the extensive pandemic scenario.

Our intent is to perform an analysis that explains the macroeconomic impacts of COVID-19 in terms of a broad set of causal factors, making this paper one of the most comprehensive in that regard to date. The research is intended to advance the academic literature and to inform policymakers by way of our decomposition of the relative effects of the various causal factors; these results indicate where the stress points are and identify points where policy interventions could help most. At the same time, our analysis points out that people and businesses are adapting quickly, as in the increase in telework, and thus individual motivations are also helping reduce the negative economic impact of the pandemic. In addition, given that there is still sizable uncertainty about major drivers, we have opted to capture this uncertainty by providing three alternative scenarios, with an emphasis on the duration, severity, and trajectory of the outbreak, which will help bound the 
magnitude of the possible impacts. These three scenarios and our decomposition analysis of particular causal factors enable the reader to ascertain even more variations in driving forces by combining components to the analysis.

\section{Scenarios}

The three scenarios examined are explained below and summarized in Table 1:

Scenarion 1: Moderate \& Declining. The virus is assumed to have moderate impacts on morbidity and mortality (300 thousand deaths in the U.S. over two years), which can be controlled to a great extent with avoidance and social distancing policies. The initial mandatory closures and minimal avoidance and social distancing measures are effective and sufficient to see a decline in cases by August 2020.

Scenarion 2: Moderate \& Increasing (No Second Wave and Vaccine). Cases rise as businesses re-open (1.25 million deaths over two years), but the U.S. chooses not to close non-essential businesses again, instead opting for more gradual reopening and social distancing and other disease spreading mitigation measures, supplemented by the effect of avoidance behavior with regard to public places. The rise in cases does not cease until January 2021, plateauing until a vaccine becomes available to the public in November 2021

Scenarion 3: Extensive \& Increasing (Second Wave and No Vaccine). Cases ramp up considerably as businesses re-open (1.75 million deaths over two years) and the U.S. is forced to close non-essential businesses again for a further six months. Cases continue to rise despite the second wave of mandatory closures and extensive avoidance and social distancing, eventually plateauing in June 2021. Avoidance and social distancing policies can stave off the rise in cases, but a vaccine would be essential to reduce the number of cases. This scenario assumes that an effective vaccine does not appear, so cases do not decline.

Overall, in all cases we examine the impact of the mandatory business closures in the U.S. and abroad that occurred prior to May 25, 2020. The scenarios differ in their assumptions regarding the trend in cases during the re-opening period: declining; increasing, thereby extending the reopening period; and extensive, resulting in a second wave of business closures. Demand for health care services increases in line with the number of cases under the alternative scenarios. A thorough search of government and other websites providing data and the literature on analyzing the economic impacts of COVID-19 has been undertaken to establish current and expected levels of avoidance and pent-up demand, with these behaviors assumed to be more extensive the longer and more severe the pandemic.

\section{General CGE Methodology}

We use the ImpactECON Supply Chain (IESC) CGE Model, developed by Walmsley and Minor (2016), ${ }^{1}$ which has been applied to analyze the supply chain impacts of several recent U.S. trade

\footnotetext{
${ }^{1}$ See also Walmsley and Minor (2020a, b) for a detailed explanation of model and data used in this analysis.
} 
Table 1 COVID-19 economic impact scenarios

\begin{tabular}{|c|c|c|c|c|c|c|c|c|}
\hline Scenario & $\begin{array}{l}\text { Severity \& } \\
\text { trend after all } \\
\text { mandatory } \\
\text { closures }\end{array}$ & $\begin{array}{l}\text { Initial } \\
\text { reopening }\end{array}$ & $\begin{array}{l}\text { Second } \\
\text { wave of } \\
\text { closure }\end{array}$ & $\begin{array}{l}\text { Second } \\
\text { wave of } \\
\text { reopening }\end{array}$ & $\begin{array}{l}\text { Travel } \\
\text { activity }\end{array}$ & $\begin{array}{l}\text { Vaccine } \\
\text { timing }\end{array}$ & $\begin{array}{l}\text { Avoidance } \\
\text { behavior }\end{array}$ & $\begin{array}{l}\text { Pent-up } \\
\text { demand }\end{array}$ \\
\hline 1. & $\begin{array}{r}\text { Moderate \& } \\
\text { Declining }\end{array}$ & 3 months & none & n.a. & minimal & none & minimal & weak \\
\hline 2. & $\begin{array}{l}\text { Moderate \& } \\
\text { Increasing: } \\
\text { No Second } \\
\text { Wave but } \\
\text { Vaccine }\end{array}$ & 12 months & none & n.a. & moderate & 18 months & extensive & moderate \\
\hline 3. & $\begin{array}{l}\text { Extensive \& } \\
\text { Increasing: } \\
\text { Second } \\
\text { Wave and } \\
\text { No Vaccine }\end{array}$ & 3 months & 6 months & 30 months & extensive & none & extensive & strong \\
\hline
\end{tabular}

policy initiatives. The model is based on, and includes all the features of, the widely used GTAP model (Hertel and Tsigas 1997; Corong et al. 2017), considered a benchmark for analysis for global trade and other policy issues. The underlying database contains input-output tables and trading relations for 65 commodities and 141 countries from the GTAP database (Aguiar et al. 2019), as well as additional detail on the source of final and intermediate goods. These data are combined with various demand and substitution elasticities to calibrate the model.

The IESC model adapts the GTAP model to include detailed trade and tariff data on the source of imported intermediate and final goods, thereby improving the analysis of global supply chain effects. In this specific case, we have more detailed information about the extent to which China and other countries supply U.S. firms with intermediate inputs used in the production process. This additional detail improves our ability to examine how the delay or disruption of these imported intermediate inputs from the rest of the world, impacts U.S. firms' ability to produce and export commodities.

The IESC model is a comparative static CGE model that provides a theoretically consistent method for analyzing the impact of global shocks on the U.S. economy. The model consists of demand for domestic and foreign goods by households, government, firms and for investment, and supply of those goods by domestic and foreign firms. It also consists of the demand (by firms) and supply (by households) of eight factors of production (five labor categories, capital, land and natural resources).

To capture the impact of the mandatory closures we reduce the production of the affected sectors, using an expedient device known as a "phantom tax" to raise prices and lower final demand. ${ }^{2}$ This is done in several iterations to take account of the indirect effects of closing sectors on other sectors. One of the benefits of these models is that they capture the indirect effects of business closures in one sector on the other sectors. For instance, as restaurants are forced to close, demand for fruit and vegetables used in producing restaurant meals, also declines. In some cases, these indirect effects are larger than the share of that sector subject to the mandatory closure, and hence we allow these

\footnotetext{
2 The taxes are set at a level that achieves a reduction in output reflecting the business closures. It is a "phantom" because the "taxes" are implicitly returned to the businesses as revenue increases associated with the higher price; essentially, the business customers (both other businesses and consumers) cover this revenue by their expenditures at the higher price, and there is no effect on government revenues.
} 
indirect effects to dominate and sectoral production to decline by more than the share of the sector subject to the mandatory closure. As a result, we only need to impose a decline in production in those sectors where the direct impacts of the mandatory closure are greater than the indirect effects from the other sectors, primarily construction and recreational services. While mandatory closures reduce production, avoidance and pent-up demand are assumed to lower and raise final demand by private consumers, respectively. In the case of avoidance of education, we also assume a decline in demand by governments.

\section{Data Sources for Health and Labor Force Impacts}

\section{Health Outcomes}

We estimate the health outcomes of COVID-19 in terms of the number of people seeking outpatient medical treatment, being hospitalized, receiving ICU treatment, or dying from the disease. The primary sources of data include CDC COVID-19 patient characteristics and treatment outcome data (CDC 2020a, b, c), the New York City Department of Health and Mental Hygiene (2020) data on population rates of COVID-19 cases, hospitalizations and deaths, and the various forecasting models of cumulative number of deaths in the U.S. The calculations below were carried out for three age groups: 0-18, 19-64, and 65+. All the health-related data used in this study were collected in May 2020, and thus reflect the health outcomes of the disease between February and mid-May of 2020. As the pandemic is rapidly evolving, recent trends in numbers of infections, hospitalizations, and fatalities of the virus are not incorporated. However, the modeling framework developed in the study can be updated as more up-to-date data become available.

First, data from several studies were gathered to estimate the percentages of people that were hospitalized, admitted to ICU, and died because of coronavirus infection with respect to the total number of confirmed cases. These estimates are summarized in Appendix Table 11 by age group and by health outcome type. These data were used to calculate the average hospitalization, ICU admission, and death percentages with respect to confirmed cases across studies for the three age cohorts in Table 2.

We also summarize the projections on cumulative COVID-19 deaths in the U.S. provided by 10 models cited in the CDC COVID-19 Forecasts website (CDC 2020d) in Appendix Table 12. The projected cumulative deaths are further disaggregated based on the information collected from the CDC Provisional Death Counts for Coronavirus Disease by age group (CDC 2020e). These results are presented in Appendix Table 13.

Next, based on the relationship between the death rate and the hospitalization rate for age groups presented in Table 2, we estimated the projected cumulative number of hospitalizations, ICU admissions, and deaths for May 30, June 6, and August 4 in Appendix Table 14. We also estimated the number of coronavirus patients who received outpatient medical treatment as the difference between the total number of cases and sum of hospitalizations (survived) and fatalities.

Based on the model projections as of May 15, the projected increase in total number of cases between June 6 and August 5 is 662,000, which translates into an average increase of 11,033 new cases each day. If we use an average of the upper-bound estimates from the forecasting models cited in Appendix Table 12, the average number of increased cases per day is estimated to be 34,226 for this time period.

To estimate the projected health outcome of COVID-19 between March 2020 and February 2022 for the three scenarios, the following assumptions are adopted to calculate the daily new 
Table 2 Average hospitalization, ICU, and fatality percentages with respect to total confirmed cases, by age group

\begin{tabular}{lrrr}
\hline Age group (yrs) & Hospitalizations & ICU admissions & Fatalities \\
\hline $0-18$ & $7.81 \%$ & $0.65 \%$ & $0.20 \%$ \\
$19-64$ & $19.32 \%$ & $4.31 \%$ & $2.16 \%$ \\
$65+$ & $39.34 \%$ & $13.61 \%$ & $10.75 \%$ \\
\hline
\end{tabular}

Sources: Average estimates calculated by the authors based on the studies presented in Appendix Table 11.

cases for each scenario. Again, all the assumptions were based on the information that was available by the end of May:

1. According to CDC data, the total number of cases by May 30 was $1,719,827$, and the average number of daily new cases was 23,478 .

2. For Scenario 1, it is assumed that, starting from June 2020, the number of daily new cases in each month declines by $40 \%$ from the previous month level until September 2020, and remains at 3000 new cases per day through February 2022.

3. For Scenario 2, it is assumed that the average daily new cases will be 29,212 in June 2020 (same as the level in April). The average daily new cases are assumed to increase by $2 \%$ afterwards in each month until they reach the plateau of about 33,000 in December 2020. The average daily cases are assumed to maintain at this level until October 2021 when a vaccine becomes available. Then the number of daily new cases starts to decline sharply to about 11,900 by February 2022 .

4. For Scenario 3, it is assumed that the average daily new cases will be 34,226 in June 2020 (the upper-bound estimate based on the forecasting model results in mid-May cited in Appendix Table 12). These cases are assumed to increase by $2 \%$ in each subsequent month of the study period.

The total cumulative number of cases are next calculated based on the above assumptions on the changes in average daily new cases over time. The total number of fatalities by the end of the 2-year study period is calculated by applying the fatality to total confirmed cases ratio as of May $2020(104,000 / 1,676,401=6.2 \%)$ to the total estimated cumulative number of cases by February 2022.

Again, based on the relationship between the death rate and the hospitalization rate for different age groups presented in Table 2 and the number of deaths in each age group, the projected cumulative number of hospitalizations with and without ICU admissions, people receiving the outpatient treatment, and fatalities are estimated and presented in Table 3 for each scenario.

Data were also collected on the morbidity rates of each country during the period. These data were then combined with the detailed data collected for the U.S. to determine the number of patients and hospitalizations. Workday loses were then assumed to occur at the same rate as in the U.S. Similarly, for health care expenditures, an adjustment was made to the cost of health care based on differences in per capita health care expenditure in each country compared to the U.S.

\section{Health Service Expenditures}

In this section, we estimate the increased spending on medical services, focusing primarily on health care expenses incurred by inpatient hospital stays or outpatient 
Table 3 Health outcome for the three scenarios, (cumulative number of people from March 2020 to February 2022)

\begin{tabular}{|c|c|c|c|c|c|}
\hline Scenarios & $\begin{array}{l}\text { Total } \\
\text { Cases }\end{array}$ & Outpatients & $\begin{array}{l}\text { Hospitalizations } \\
\text { non-ICU }\end{array}$ & $\begin{array}{l}\text { Hospitalizations } \\
\text { ICU }\end{array}$ & Fatalities \\
\hline 1. Moderate \& Declining & $4,169,409$ & $2,685,700$ & 859,818 & 365,231 & 258,660 \\
\hline $\begin{array}{l}\text { 2. Moderate \& Increases: No } \\
\text { Second Closure but Vaccine }\end{array}$ & $20,179,700$ & $12,998,634$ & $4,161,468$ & $1,767,696$ & $1,251,901$ \\
\hline $\begin{array}{l}\text { 3. Extensive \& Increasing: Second } \\
\text { Closure and No Vaccine }\end{array}$ & $28,193,853$ & $18,160,904$ & $5,814,151$ & $2,469,717$ & $1,749,081$ \\
\hline
\end{tabular}

Source: Estimated based on data presented in Appendix 1

medical treatment received by the COVID-19 patients. We first collected data on the projected costs for COVID-19 patients that require an inpatient hospital stay. According to Cohen et al. (2020), the allowed cost of non-ICU patients is estimated to be $\$ 12,450$ for Commercial health insurance, $\$ 8850$ for Medicare Advantage Organizations, and $\$ 6800$ for Medicaid managed care organizations (MCO). The estimated allowed cost for ICU patients is $\$ 38,450, \$ 17,000$, and $\$ 16,250$ for Commercial insurance groups, Medicare Advantage, and Medicaid MCO, respectively (Cohen et al. 2020). Based on the share of people enrolling in these three types of health insurance plans, the weighted average allowed cost is $\$ 11,050$ for non-ICU patients and $\$ 30,950$ for ICU patients.

Similarly, in FAIR Health (2020), per patient cost of inpatient stay is provided for the estimated commercial insurance allowed amount, Medicare reimbursement amount, and Medicaid reimbursement amount. The weighted average per patient cost is again calculated using the number of people utilizing each type of health insurance plans as the weights. The weighted average cost is $\$ 29,115$ for patients with major complication or comorbidity (indicated by diagnosis-related groups (DRG) code 193) and $\$ 17,320$ for those with no complication or comorbidity (indicated by DRG code 195). We use the former to approximate the cost for ICU patients and the latter for non-ICU patients.

In our analysis, we use the average of the cost estimates provided in the Wakely report (Cohen et al. 2020) and the FAIR Health 2020 report, which is $\$ 30,033$ for ICU patients and $\$ 14,185$ for non-ICU patients. Average per patient cost for people who only received outpatient treatment and other professional service is estimated to be $\$ 387.43$ (Cohen et al. 2020). ${ }^{3}$

Table 4 presents the total medical expenditures based on the projected health outcome of the three scenarios.

\section{Workday Losses}

Appendix Table 15 summarizes the length of illness onset to hospitalization, as well as length of hospital stay, for both non-severe and severe cases based on several studies we reviewed. Based on these data, we assume that the average hospital stays for non-severe and severe (ICU admitted) COVID-19 patients are 10 days and 15.5 days, respectively. The average length from illness onset to hospitalization is 4.5 days. If we further assume that there will be an

\footnotetext{
${ }^{3}$ Note that all the cost estimates presented and calculated above refer to insurance allowed amounts rather than health provider charges. Patients sometimes are asked to pay a good proportion of the difference between the charged and allowed amounts, especially if they use out-of-network services. However, because of the uncertainty with the balance billing and the fact that many patients are treated by preferred providers, we use the allowed cost estimates in our analysis.
} 
Table 4 Total medical expenditures (in millions of 2020 dollars)

\begin{tabular}{llllrr}
\hline Scenario & Outpatient medical treatment & Hospitalizations non-ICU & Hospitalizations ICU & Fatalities & Total \\
\hline 1 & 1041 & 12,197 & 10,969 & 7768 & 31,974 \\
2 & 5036 & 59,030 & 53,089 & 37,598 & 154,754 \\
3 & 7036 & 82,474 & 74,173 & 52,530 & 216,213 \\
\hline
\end{tabular}

Source: calculated by the authors based on per patient cost data collected from Cohen et al. (2020) and FAIR Health (2020)

additional 3 days for non-severe patients and 5 days for severe patients to fully recover before they can return to work after hospital discharge, the total productivity losses are 17.5 days for non-severe patients and 25 days for severe patients. For patients that only received outpatient treatment, we utilized the data from Prager et al. (2017): 1.5, 1.9, and 5.3 days, respectively, for the three age groups.

Lost productivity due to own illness is presented in Table 5. For each health outcome category, we multiply the projected number of patients in Table 3 by the corresponding number of lost productivity days per person, and adjust for the labor force participation rate of $63.4 \%$ in February 2020 (BLS 2020).

Table 6 presents the lost productivity due to caring for sick family members. These include caring for sick children in the 0-18 age group, sick spouse in the 18-64 age group, and sick elderly family members in the 65+ age group. We made similar assumptions as in Prager et al. (2017) and Dixon et al. (2010) in calculating the productivity day losses due to the care of sick family members. The data and assumptions adopted in the calculations are discussed in Appendix 2.

\section{Mandatory Shutdown and Reopening}

\section{Mandatory Shutdown between March and June 2020}

The mandatory shutdown and "stay-at-home" orders implemented in individual states between March and June in the U.S. are presented in Appendix Table 17 in terms of the order declared date, order expiration date, and the length (days) of the order.

In order to determine the impacts of mandatory closures on different economic sectors, we first divided the sectors into three categories based on the list of Essential Critical Infrastructure Sectors during COVID-19 defined by DHS Cybersecurity and Infrastructure Security Agency:

Category 1 refers to sectors that fall entirely under the non-essential category and thus are shut down under the mandatory closures (some examples of such sectors

Table 5 Lost productivity due to own illness (days)

\begin{tabular}{|c|c|c|c|c|c|}
\hline Scenario & Outpatient medical treatment & $\begin{array}{l}\text { Hospitalizations } \\
\text { non-ICU }\end{array}$ & $\begin{array}{l}\text { Hospitalizations } \\
\text { ICU }\end{array}$ & Fatalities & Total \\
\hline 1 & $5,476,818$ & $10,306,035$ & $6,253,951$ & $32,332,550$ & $54,369,352$ \\
\hline 2 & $26,507,481$ & $49,880,613$ & $30,268,761$ & $156,487,676$ & $263,144,533$ \\
\hline 3 & $37,034,645$ & $69,690,169$ & $42,289,678$ & $218,635,093$ & $367,649,585$ \\
\hline
\end{tabular}


Table 6 Lost productivity due to caring of sick family members (days)

\begin{tabular}{llrrr}
\hline & Age group & Scenario 1 & Scenario 2 & Scenario 3 \\
\hline Outpatient Medical Treatment & $0-17$ & 65,135 & 315,250 & 440,448 \\
& $18-64$ & 138,902 & 672,277 & 939,264 \\
& $65+$ & 276,624 & $1,338,844$ & $1,870,551$ \\
Hospitalizations Non-ICU & $0-17$ & 30,960 & 149,844 & 209,353 \\
& $18-64$ & 262,597 & $1,270,956$ & $1,775,703$ \\
& $65+$ & 525,891 & $2,545,281$ & $3,556,112$ \\
Hospitalizations ICU & $0-17$ & 3988 & 19,303 & 26,969 \\
& $18-64$ & 107,584 & 520,700 & 727,490 \\
Fatalities & $65+$ & 397,332 & $1,923,064$ & $2,686,789$ \\
& $0-17$ & 1250 & 6050 & 8453 \\
& $18-64$ & 53,894 & 260,845 & 364,437 \\
Total & $65+$ & 313,957 & $1,519,533$ & $2,122,999$ \\
& & $2,178,114$ & $10,541,947$ & $14,728,569$ \\
\hline
\end{tabular}

include Non-critical Manufacturing, Recreation \& Entertainment, Education). However, we considered telework potentials that help reduce the direct impacts of shutdowns in these sectors.

Category 2 refers to sectors that only some of their subsectors are non-essential. Some examples in this category include Retail Trade (e.g., Grocery Stores, Special Food Stores, Gas Stations, etc. are excluded from shutdowns), Food Services, Business Services.

Category 3 refers to sectors that are essential and therefore the sectors in this category are able to maintain operation in their usual manner to the extent possible. Example sectors in this category include Agriculture, Utilities, Critical Manufacturing, etc.

Appendix Table 18 presents the percentage reduction in U.S. annual GDP by sector due to mandatory closures for each of the three scenarios. These estimates also factored in telecommuting for non-essential sectors covered under the mandatory closure order, but only for those that can produce output by telecommuting to some extent. The telework potentials by sector are presented in Appendix Table 19.

We note three recent papers, two of which have used different data sources than ours. For example, both Dingel and Neiman (2020) and Dey et al. (2020) used Occupational Information Network (O*NET) surveys, while we used the BLS data that were based on American Time Use Survey. Although both of these two data sources represent pre-COVID conditions, Dingel and Neiman and Dey et al. found a higher proportion of workers that have telework capability. However, in some other respects, we have allowed for much more telework than these papers found because we assumed that, if a person could telework for just one day a week, they could telework for the entire week during a pandemic. In terms of changes in worker productivity, although we agree that the productivity of some people was affected by telework, especially working parents with children engaging in online or hybrid models of learning, other studies have found that many people experience increased productivity working from home because of time savings from commuting, fewer distractions from co-workers, and fewer in-person meetings (Schrotenboer 2020). Given these factors that affect productivities in both directions, we have not assumed a change in productivity in our base cases. However, this consideration and others are 
included in the sensitivity tests of increases and decreases in telework potential in an attempt to provide more insights on the implications of variability in telework on our results. 4

\section{Reopening Process}

For the reopening of the U.S. economy in terms of the duration of the process and the percentage of non-essential sectors that will reopen in each phase-in stages, we referred to the reopening plans of five major states that were released at the end of May: California, Texas, New York, Illinois, and Florida. The detailed reopening stages and timelines are presented in Appendix Table 20. We further made the following assumptions:

- Phase I: Assume the disrupted production under the mandatory closure orders of the following non-essential sectors or sub-sectors will be reduced by half: non-essential manufacturing, construction, wholesale and retail trade, accommodation, food and service activities, other services (government). The other non-essential sectors (such as business services, recreation \& other services and education) remain the same closure status.

- Phase II: Assume the disrupted production of the following non-essential sectors or subsectors will be further reduced to only $25 \%$ of the output reductions during the mandatory closure period: non-essential manufacturing, construction, wholesale and retail trade, accommodation, food and service activities, other services (government). The output disruptions of the remaining non-essential sectors, except for recreation and education, will be reduced by half.

- Phase III: Assume the following non-essential sectors or sub-sectors will be fully reopened: non-essential manufacturing, construction, wholesale and retail trade, accommodation, food and service activities, other services (government). The output disruptions of the remaining non-essential sectors, except for recreation and education, will be further reduced to only $25 \%$ of the output reductions during the mandatory closure period. Recreation and Education sectors will be half reopened and operate at $50 \%$ baseline level.

- After the reopening period (3-months or 12-months, depending on the scenarios), we assume that all sectors will be open entirely.

The $50 \%$ and $25 \%$ production disruption reductions are based on the expectation that, after the lockdowns or business closures, businesses would only be able to slowly reopen with limitations. For example, in the earlier stages, although low-risk businesses can open, modifications are required to ensure distancing (such as in retail sector and office spaces). In later phases, although higher-risk businesses can open, there are other restrictions. For example, only outdoor museums can open first; restaurants and bars can only operate at $50 \%$ to $75 \%$ of

\footnotetext{
${ }^{4}$ In the case of the rest of the world, data were collected on the actual timings of mandatory closures of each country taken from Wikipedia (2020). Where these closures were considered partial (e.g., city- or region- wide only) we applied a 50\% closure rate. The mandatory closures in China are calculated based on actual closures of businesses in Hubei Province and Wuhan City in China and extension of the Chinese new year holidays in rest of the country, as well as partial closures as the businesses across the country gradually resumed production in late February through early April. Each country's production data were then used to determine the share of the sector closed, assuming the same essential sector shares as in the U.S. case. U.S. reopenings were also used to determine the timing of reopenings for the rest of the world, adjusted for differences in the mandatory closure periods between each country and the U.S.
} 
capacity; and spectator sporting events need to limit occupancy venues of $50 \%$ of the building capacity. There is considerable variation in the re-opening phase across states. California reversed the re-opening on July 13, with statewide restrictions to again halt all indoor dining and close bars, zoos and museums. Illinois took only 1.5 months to get to Phase 4, while Florida took one month to get to Phase 2.

Appendix Table 21 presents the percentage reduction in U.S. annual GDP by sector due to the phased-in reopening process for each of the three scenarios. Again, the estimates also factor in the effects of telecommuting.

\section{Other Explanatory Factors}

\section{Avoidance Behavior}

We gathered survey data from public opinion polls or surveys around avoidance behavior in response to COVID-19 pandemic. Data on avoidance behavior trends as a result of the coronavirus before states implemented shutdown orders were gathered from 11 public opinion polls before the announcement of shelter-in-place rules in California and New York. People's willingness to resume activities after their state lifts shutdown orders were collected from 9 public opinion polls conducted in May. Survey data are summarized in Appendix $4 .^{5}$

In our scenario analysis, three levels (low, moderate, high) of avoidance behavior are simulated with respect to the magnitude and length of such behaviors. Appendix Table 23 summarize the parameters we estimated based on the various public opinion polls reviewed in Appendix 4. The methods and additional assumptions we adopted to translate the survey results in each study to low, moderate, and high estimates are also summarized in Appendix 4.

Table 7 summarizes the assumptions on the magnitude of various types of avoidance behavior in terms of percentage of people that are likely to practice them. In cases where multiple polls asked similar questions, we take an average of the poll results. The last column of Table 6 presents the method to simulate the impacts of the avoidance behavior in the CGE Model. We assume the duration that people will practice the various types of avoidance behavior after the lift of mandatory closures is 3 weeks, 3 months, and 6 months for Scenarios 1,2 , and 3 , respectively. ${ }^{6}$ Other countries were assumed to avoid at the same rates as the U.S.

\section{Savings}

Data on the U.S. personal savings rate show a rise in the personal savings rate from $7.9 \%$ to $33 \%$ during the first few months of the pandemic (Trading Economics 2020, for US data, and World Bank 2020, for China and ROW). Savings rates rise due to the increase in demand for

\footnotetext{
$\overline{5}$ Data on avoidance behavior were gathered from 11 polls that were taken before the shutdown orders and 9 that were taken after at least one state had implemented stay-at-home orders. We primarily used the 11 polls taken before shutdown orders because they better capture avoidance behavior, whereas the ones taken after the stay-athome orders conflate avoidance behavior with compliance to existing government orders. The 11 polls we used surveyed adults in all 50 states, and were weighted to be nationally representative. The sample size varies from 900 respondents to nearly 4300 respondents. Most of the surveys used around 1000-1200 respondents.

${ }^{6}$ Only one poll explicitly examined public opinion in relation to duration of avoidance behavior by asking people whether they think it is safe to resume educational activities and reopen theaters, restaurants, and bars in several weeks, several months or six months or more. We used this information as the basis of our assumptions about the duration of avoidance behavior based on the severity of the pandemic in each scenario.
} 
Table 7 Assumptions on magnitude of avoidance behaviors and CGE modeling method

\begin{tabular}{|c|c|c|c|c|}
\hline \multirow[t]{2}{*}{ Avoidance behavior } & \multicolumn{3}{|c|}{ Percent avoided } & \multirow[t]{2}{*}{ CGE modeling linkage } \\
\hline & Low & Moderate & High & \\
\hline Staying home from work & $13 \%$ & $18 \%$ & $22 \%$ & $\begin{array}{l}\text { Reduce workforce participation; adjusted for weighted } \\
\text { average telework potential across sectors }\end{array}$ \\
\hline $\begin{array}{l}\text { Keeping children from } \\
\text { school }\end{array}$ & $32 \%$ & $53 \%$ & $66 \%$ & Reduce demand in education sector \\
\hline $\begin{array}{l}\text { Keeping children from } \\
\text { school (caregiver } \\
\text { avoidance) }\end{array}$ & $32 \%$ & $53 \%$ & $66 \%$ & $\begin{array}{l}\text { Reduce workforce participation in order to care for } \\
\text { children (further factor in \% of families with Children } \\
\text { but with no stay-at-home parents) }\end{array}$ \\
\hline $\begin{array}{l}\text { Avoiding medical } \\
\text { professionals }\end{array}$ & $20 \%$ & $35 \%$ & $50 \%$ & $\begin{array}{l}\text { Assume people would defer spending; some proportion of } \\
\text { the delayed discretionary medical expenditures are part } \\
\text { of pent-up-demand }\end{array}$ \\
\hline Reducing shopping & $34 \%$ & $48 \%$ & $61 \%$ & $\begin{array}{l}\text { Reduce demand in mall/storefront shopping (under Retail } \\
\text { Trade) }\end{array}$ \\
\hline $\begin{array}{l}\text { Avoiding local leisure } \\
\text { activities }\end{array}$ & $38 \%$ & $46 \%$ & $53 \%$ & Reduce demand in recreation sector \\
\hline Avoiding dining in & $27 \%$ & $41 \%$ & $56 \%$ & Reduce demand in restaurants and bars sectors ${ }^{a}$ \\
\hline $\begin{array}{l}\text { Avoiding public } \\
\text { transportation }\end{array}$ & $44 \%$ & $58 \%$ & $72 \%$ & Reduced demand in public transportation sector \\
\hline Canceling travel plans & $43 \%$ & $56 \%$ & $69 \%$ & $\begin{array}{l}\text { Allocated by BEA data on the travel expenditures in } \\
\text { among consumption categories (BEA 2019) }\end{array}$ \\
\hline
\end{tabular}

a These percentages are only applied to the dining-in portion of restaurant services because we assume that the take-out services would be less affected by the avoidance behavior.

precautionary savings and as closures and avoidance behavior make it difficult, or even impossible, to purchase non-essential items, resulting in people putting aside the extra savings for future purchases (pent-up demand). The increased savings rates obtained are used as the basis for Scenario 2, and then are adjusted slightly to reflect differences in the avoidance in Scenarios 1 and 3 .

Savings rates are assumed to increase with the mandatory closures and then again with increased avoidance. Savings rates then diminish with increased health care costs and pent-up demand. We assume a similar path for changes in the savings rates of China and the rest of world, although the increase is assumed to be more muted given the relatively higher initial savings rates.

\section{Communications}

Shutdown orders led to an increase in internet traffic due to remote working and learning. Comscore (2020) estimates that average home data consumption was up 33\% in early May 2020 relative to the same period the previous year. The orders also resulted in higher wireless calls and data usage. However, the increase in traffic does not translate into equivalent revenue growth for broadband providers, wireless carriers, and internet companies. While broadband providers and wireless carriers experienced service revenue increases, those increases are lower than total data usage increase as many consumers pay a flat subscription fee. Furthermore, while internet companies may have seen increased internet traffic, their revenues are based on advertisement demand, which declined along with the consumer demand shock. The estimation of 
those impacts is presented in Appendix 5 based on information from the quarterly earnings reports of major public companies.

In sum, we found that the Internet Publishing and Broadcasting and Web Search Portals sector actually experienced a $10 \%$ to $30 \%$ decrease in revenue because of the sharp decline in advertisement revenue during the mandatory closure period. We assume that this impact is subsumed in the $10 \%$ output reduction in the entire Information and Communications sector (see Appendix Table 18). For the other three sectors, we assume Wired Telecommunications Carriers is estimated to have a $0.25 \%$ increase in revenue, Wireless Telecommunications Carriers has a $0 \%$ increase in revenue, and Data Processing, Hosting, and Related Services a $1 \%$ increase in revenue. Similar increases in communications were assumed in the rest of the world and China.

\section{Pent-Up Demand}

Appendix Table 25 presents the estimates of pent-up consumer demand resulting from the COVID-19 related lockdowns across a range of key sectors, goods, and services in the U.S. The estimates provided were calculated using micro-level data from three distinct online sources: Opportunity Insights (2020), Unacast (2020), and SafeGraph (2020). Estimates for pent-up demand for each category are provided using both the "Lowest Point" and "May 1" levels. Lowest point signifies a pent-up demand calculation using the single largest decline in either consumer spending (in the case of Opportunity Insights) or foot traffic at the indicated area of interest (in the case of both Unacast and SafeGraph). May 1 estimates are provided under the rationale that pent-up demand may have begun being released at the beginning of May as opposed to immediately following the departure from the lowest point, because many U.S. states eased lockdowns to some degree around this time period (however, with recent end-of-lockdown reversals this metric may be less meaningful).

Based on the pent-up demand data collected in Appendix Table 25, we determined pent-up demand in percentage terms for three various levels: weak, moderate, and strong in Table 8 , where these levels are used as inputs in the simulations of our scenarios. In the second to last column in Table 8, we map the consumption good/service categories to the relevant GTAP sectors, with shares of the pent-up demand goods or services presented in the last column. The GTAP sectoral shares of the pent-up demand goods and services were calculated based on the output data for the 536 more disaggregated sectors obtained from IMPLAN U.S. I-O table (IMPLAN 2018), and then aggregated to match the sectoring scheme of our CGE model. Similar pent-up demand rates were assumed in the rest of the world and China.

\section{Travel}

Travel enters into the analysis in a number of ways, which are worth reviewing, including as: a) avoidance of public transportation, b) the mandatory shutdown of parts of the transportation sector in the US and abroad, and c) a decline in international trade in services due to the decline in international travel, which may be the result of a travel ban or avoidance of international travel. The decline in international trade in services is in line with the mandatory closures, so we do not capture these nuances in travel bans in our analysis. Moreover, we generally find that the impact of the reduced international travel is drowned out by the overall trade impacts of the other policies and behaviors (e.g., the mandatory closures). 
Table 8 Pent-up demand assumptions and mapping to CGE sectors

\begin{tabular}{|c|c|c|c|c|c|}
\hline Good/Service & $\begin{array}{l}\text { Weak } \\
\text { (Scenario } \\
\text { 1) }\end{array}$ & $\begin{array}{l}\text { Moderate } \\
\text { (Scenario } \\
\text { 2) }\end{array}$ & $\begin{array}{l}\text { Strong } \\
\text { (Scenario } \\
\text { 3) }\end{array}$ & GTAP Sector & $\begin{array}{l}\text { Share of } \\
\text { GTAP } \\
\text { Sector }\end{array}$ \\
\hline Automobiles & $50 \%$ & $70 \%$ & $90 \%$ & $\begin{array}{l}50 \text { Wholesale and Retail Trade; } \\
\text { Repair of Motor Vehicles }\end{array}$ & $5.5 \%$ \\
\hline Real estate & $30 \%$ & $50 \%$ & $70 \%$ & 59 Real Estate Activities & $100 \%$ \\
\hline Air travel & $5 \%$ & $15 \%$ & $35 \%$ & 54 Air Transport & $94.10 \%$ \\
\hline Restaurant dining & $40 \%$ & $60 \%$ & $80 \%$ & $\begin{array}{l}51 \text { Accommodation, Food and } \\
\text { Service Activities }\end{array}$ & $71.7 \%$ \\
\hline $\begin{array}{l}\text { Live experiences (sporting } \\
\text { events, concerts, etc.) }\end{array}$ & $13 \%$ & $33 \%$ & $53 \%$ & $\begin{array}{l}61 \text { Recreation \& Other } \\
\text { Services }\end{array}$ & $16.5 \%$ \\
\hline Apparel & $50 \%$ & $70 \%$ & $90 \%$ & $\begin{array}{l}50 \text { Wholesale and Retail Trade; } \\
\text { Repair of Motor Vehicles }\end{array}$ & $4.1 \%$ \\
\hline General Merchandise & $70 \%$ & $90 \%$ & $90 \%$ & $\begin{array}{l}50 \text { Wholesale and Retail Trade; } \\
\text { Repair of Motor Vehicles }\end{array}$ & $6.8 \%$ \\
\hline $\begin{array}{l}\text { Hotels and other } \\
\text { hospitality }\end{array}$ & $30 \%$ & $50 \%$ & $70 \%$ & $\begin{array}{l}51 \text { Accommodation, Food and } \\
\text { Service Activities }\end{array}$ & $16.8 \%$ \\
\hline Movie theaters & $5 \%$ & $10 \%$ & $30 \%$ & $\begin{array}{l}56 \text { Information and } \\
\text { Communication }\end{array}$ & $8.7 \%$ \\
\hline Wellness and fitness & $30 \%$ & $50 \%$ & $70 \%$ & $\begin{array}{l}61 \text { Recreation and Other } \\
\text { Services }\end{array}$ & $3.0 \%$ \\
\hline
\end{tabular}

\section{Simulation Specification}

The CGE model is comparative static and set up to examine the short-run implications of the pandemic. The comparative static nature of the model limits our ability to trace all of the dynamic impacts of the pandemic over its time-path and in particular during the recovery period. Our strategy is to simulate the short-run negative impacts of the mandatory closures, partial reopening, avoidance behavior, morbidity and mortality and health care. We then add back the impact of pent-up demand - that is the portion of production lost during the pandemic due to the other factors, which could eventually be recovered as consumers buy goods they were unable to obtain during the pandemic. Previously laid-off workers will be rehired to meet this pent-up demand, and GDP will rise towards baseline growth.

Our approach and its relationship to a fully dynamic analysis is illustrated in Fig. 1 in Appendix 7. While the pent-up demand is an important part of the recovery process, it is worth noting that the increase in GDP it stimulates does not reflect the full extent of the recovery process because we do not consider the inevitable rise in GDP as consumers resume their normal activities, and unemployed workers accept lower wages in order to get back into the labor market. This is analogous to looking at the economic impact of the COVID-19 and the mandatory closures in the troughs of these time-path curves, approximately a year after the beginning of the pandemic (see again Fig. 1, as well as the scenario descriptions in Appendix 7). As a result, the percent declines in GDP, for instance, represents the extent to which GDP will be below what it otherwise would have been at the bottom of this trough. We use a very short-run closure rule in which we assume factors of production (including capital and labor) are not mobile across sectors and any fall in demand of a factor will result in its unemployment. We also assume real private consumption of essential goods and services is fixed, and that households will first use their income to purchase food and utilities. Government expenditure is also fixed, and hence the government deficit is assumed to adjust to any 
changes in tax revenues, as production and demand fall. Trade balances are determined endogenously. This reflects the decision to allow any increase in savings in the U.S. to move abroad rather than increase domestic investment. ${ }^{7}$ Increased private savings is also assumed to fund any changes in the government deficit.

In each scenario we decompose the results into the following parts:

- Mandatory closures and re-openings - impact of the mandatory closure of businesses and associated reopening process across the U.S. and the world in response to the outbreak of COVID-19. These mandatory closures also take into account the extent to which a sector can continue to produce remotely through telework. With the lack of availability of nonessential goods and services, their consumption declines, and thus savings rise considerably.

- Avoidance - impact of consumers avoiding activities that would put a person at increased risk of contracting the virus. Consumers are assumed to avoid work, in-class learning, ${ }^{8}$ restaurants and other social activities even after the mandatory closures have been lifted and businesses reopen. Purchases avoided are assumed to further raise the savings rate. It is worth noting that any avoidance behavior that occurs during the mandatory closure of business is subsumed into the mandatory closures effect.

- Communications - increase in working from home increases the demand for internet and communications considerably. Production in part of this sector rises to reflect this increase in demand.

- Morbidity and Mortality - impact on the labor force of an increase in sickness and deaths, including days taken off to care for sick family members. The increase in deaths also lowers the population and demand for private consumption, including essential goods.

- Health - increase in demand for health care services by the private sector and government. Government expenditure is assumed to rise and the deficit to increase in line with the increase in demand for health care. We also assume that the health care sector has considerable excess capacity (assuming a 60\% utilization rate of capital in the health care sector), due to normal excess capacity levels and the ability to delay non-emergency procedures (Cox et al. 2020). ${ }^{9}$

\footnotetext{
${ }^{7}$ Although incomes and hence savings are falling as a result of the pandemic, savings rates are rising dramatically with increased precautionary savings and as mandatory closures and avoidance behavior make it difficult or even impossible to purchase non-essential items. Savings rates rise most in the U.S. where savings rates are historically very low. Moreover, in the model, all savings must be invested - savings cannot be placed 'under the mattress'. Under the assumption of a fixed trade balance, the relative increase in U.S. savings must be invested in the U.S., making investment in the U.S. increase relative to other countries. In reality this is unlikely: first, a lot of this increase in savings is temporary - related to pent-up demand (delayed purchases); second, the closure of a significant proportion of the construction and related sectors means that this savings cannot be invested in the construction of capital goods; and finally, the level of uncertainty regarding the ability of different countries to control the pandemic has been significant and is likely to cause savers to be very cautious about where they invest. To mitigate the impact of this issue on the U.S economy results, we assume that the trade balance is endogenous, thereby sharing the increase in savings, and its impact on an economy, across all countries.

${ }^{8}$ Note that we also assume government demand for education falls.

${ }^{9}$ In the case of the decline in health care visits, this is captured in our second and third scenarios - as lockdowns continue and incomes fall, demand and supply of other health care services fall. In the first scenario, however, we do not include a decline in other health care services in order to have some variability across scenarios.
} 
- Pent-up demand - extent to which demand lost during the mandatory closures is recovered when businesses re-open as consumers use their savings to buy items they could not during the shutdown. We assume savings falls and demand rises.

\section{Results}

The GDP impacts of Scenario 1 are presented in percentage terms in Table 9 for the U.S., China and Rest of the World. The results are decomposed according to the causal factors described in the previous section, though with some combining where appropriate. Overall, the total impact on the U.S. economy is a $\$ 3.2$ trillion, or $14.8 \%$, decline in GDP. The percentage results are almost 3 times higher in the U.S. than in China and nearly $50 \%$ higher than in the Rest of the World (ROW).

The major factors affecting the results are Mandatory Closures and the partial reopenings of businesses. These alone would have resulted in a $22.3 \%$ decrease in the U.S. GDP, ${ }^{10}$ but only about $40 \%$ of that amount in China because of the much shorter lock-down period in the latter. The results for ROW fall about half-way in-between the other two regions.

The impacts of the other causal factors are simulated in a semi-dynamic way, where each type of shock is added to the previous ones, rather than being simulated in isolation. First, avoidance behavior impacts are simulated with mandatory closures/partial reopenings and reflect continued avoidance behaviors after reopening, rather than avoidance behavior during the mandatory closure period, which is dominated by the mandatory closures themselves. In Scenario 1 we also assume weak additional avoidance behavior as we assume the mandatory closures have been effective at reducing the number of COVID-19 cases and deaths and further avoidance after reopening is low. As a result, they have an almost imperceptible impact in all three regions.

Increased communication expenditures have a very slightly positive effect in all three regions. Note also that the communication expenditures reflect, to a great extent, one of the major resilience responses of telecommuting. The much smaller positive effects in China are due to the relatively much shorter shutdown duration.

Death and illness impacts are relatively negligible on the economy in percentage terms due to the high levels of unemployment caused by the mandatory closures, which again dominate the economic impact. Health care expenditure impacts are also relatively small in Scenario 1. Note that these expenditures have a positive impact on GDP, since the economy is not in full employment and consumer expenditures on other items are suppressed by the closures, thereby freeing up disposable income without an otherwise dampening effect on the economy. ${ }^{11}$

Pent-up Demand is the second most influential factor by far and offsets the mandatory closures/partial reopenings by about $30 \%$ of mandatory closure impacts for all three regions.

\footnotetext{
${ }^{10}$ A comparison of the analysis to recent data suggests that our results are on the high side - reflecting the fact that we are looking at a 2-year time horizon, and we expected the mandatory closures and gradual re-opening to go longer, especially in the more severe scenarios and that there could be less resilience/adaptation. However, it is still too early to tell how all of these assumptions will pan out over the course of the coming year.

${ }^{11}$ Note that workday losses stemming from death and illness, as well as caring for sick family members, do not result in noticeable GDP impacts in any of the three scenarios because they do not represent an effective constraint on the labor force. This is primarily because demand for goods and services declined significantly, thereby reducing the drive of demand for labor.
} 
Table 9 Real GDP Impacts (billions of U.S. dollars and percent changes relative to baseline)

\begin{tabular}{|c|c|c|c|c|c|c|c|}
\hline $\begin{array}{l}\text { Country/ } \\
\text { region }\end{array}$ & $\begin{array}{l}\text { Mandatory } \\
\text { closure } \\
\& \text { reopening }\end{array}$ & Avoidance & $\begin{array}{l}\text { Communication } \\
\text { demand }\end{array}$ & $\begin{array}{l}\text { Deaths } \\
\text { and Illness }\end{array}$ & $\begin{array}{l}\text { Health care } \\
\text { expenditure }\end{array}$ & $\begin{array}{l}\text { Pent-up } \\
\text { demand }\end{array}$ & $\begin{array}{l}\text { Total } \\
\text { impacts }\end{array}$ \\
\hline \multicolumn{8}{|c|}{ Scenario 1} \\
\hline USA & $\begin{array}{r}-4780.8 \\
(-22.3)\end{array}$ & $\begin{array}{l}-6.7 \\
(0.0)\end{array}$ & $\begin{array}{r}208.7 \\
(1.0)\end{array}$ & $\begin{array}{l}-0.7 \\
(0.0)\end{array}$ & $\begin{array}{l}21.4 \\
(0.1)\end{array}$ & $\begin{array}{r}1394.3 \\
(6.5)\end{array}$ & $\begin{array}{r}-3163.7 \\
(-14.8)\end{array}$ \\
\hline China & $\begin{array}{r}-1210.9 \\
(-8.6)\end{array}$ & $\begin{array}{l}-7.9 \\
(-0.1)\end{array}$ & $\begin{array}{l}83.3 \\
(0.6)\end{array}$ & $\begin{array}{c}0.0 \\
(0.0)\end{array}$ & $\begin{array}{c}0.2 \\
(0.0)\end{array}$ & $\begin{array}{c}394.2 \\
(2.8)\end{array}$ & $\begin{array}{r}-741.2 \\
(-5.2)\end{array}$ \\
\hline ROW & $\begin{array}{r}-8301.9 \\
(-15.8)\end{array}$ & $\begin{array}{l}-66.7 \\
(-0.1)\end{array}$ & $\begin{array}{r}710.8 \\
(1.4)\end{array}$ & $\begin{array}{l}-0.3 \\
(0.0)\end{array}$ & $\begin{array}{c}4.5 \\
(0.0)\end{array}$ & $\begin{array}{r}2503.7 \\
(4.8)\end{array}$ & $\begin{array}{r}-5123.1 \\
(-9.8)\end{array}$ \\
\hline \multicolumn{8}{|c|}{ Scenario 2} \\
\hline USA & $\begin{array}{r}-8040.1 \\
(-37.5)\end{array}$ & $\begin{array}{r}-853.2 \\
(-4.0)\end{array}$ & $\begin{array}{r}263.2 \\
(1.2)\end{array}$ & $\begin{array}{l}-23.7 \\
(-0.1)\end{array}$ & $\begin{array}{r}966.3 \\
(4.5)\end{array}$ & $\begin{array}{r}3821.1 \\
(17.8)\end{array}$ & $\begin{array}{r}-3866.5 \\
(-18.0)\end{array}$ \\
\hline China & $\begin{array}{r}-2392.3 \\
(-16.9)\end{array}$ & $\begin{array}{r}-758.8 \\
(-5.4)\end{array}$ & $\begin{array}{r}174.1 \\
(1.2)\end{array}$ & $\begin{array}{c}0.2 \\
(0.0)\end{array}$ & $\begin{array}{r}531.4 \\
(3.8)\end{array}$ & $\begin{array}{r}1434.4 \\
(10.1)\end{array}$ & $\begin{array}{r}-1010.9 \\
(-7.1)\end{array}$ \\
\hline ROW & $\begin{array}{r}-13,943.1 \\
(-26.6)\end{array}$ & $\begin{array}{r}-3282.2 \\
(-6.3)\end{array}$ & $\begin{array}{r}1395.4 \\
(2.7)\end{array}$ & $\begin{array}{c}3.5 \\
(0.0)\end{array}$ & $\begin{array}{r}1613.2 \\
(3.1)\end{array}$ & $\begin{array}{r}7852.4 \\
(15.0)\end{array}$ & $\begin{array}{r}-6360.8 \\
(-12.1)\end{array}$ \\
\hline \multicolumn{8}{|c|}{ Scenario 3} \\
\hline USA & $\begin{array}{r}-12,996.8 \\
(-60.6)\end{array}$ & $\begin{array}{r}-885.1 \\
(-4.1)\end{array}$ & $\begin{array}{r}5277.8 \\
(2.7)\end{array}$ & $\begin{array}{l}-5.1 \\
(0.0)\end{array}$ & $\begin{array}{r}189.8 \\
(0.9)\end{array}$ & $\begin{array}{r}8186.6 \\
(38.2)\end{array}$ & $\begin{array}{r}-4932.8 \\
(-23.0)\end{array}$ \\
\hline China & $\begin{array}{r}-3513.0 \\
(-24.8)\end{array}$ & $\begin{array}{r}-539.8 \\
(-3.8)\end{array}$ & $\begin{array}{r}119.3 \\
(0.8)\end{array}$ & $\begin{array}{l}-0.2 \\
(0.0)\end{array}$ & $\begin{array}{c}1.2 \\
(0.0)\end{array}$ & $\begin{array}{r}2993.5 \\
(21.2)\end{array}$ & $\begin{array}{r}-939.0 \\
(-6.6)\end{array}$ \\
\hline ROW & $\begin{array}{r}-26,251.3 \\
(-50.0)\end{array}$ & $\begin{array}{r}-2596.3 \\
(-4.9)\end{array}$ & $\begin{array}{r}1768.1 \\
(3.4)\end{array}$ & $\begin{array}{c}1.1 \\
(0.0)\end{array}$ & $\begin{array}{l}22.1 \\
(0.0)\end{array}$ & $\begin{array}{r}17,697.1 \\
(33.7)\end{array}$ & $\begin{array}{r}-9359.3 \\
(-17.8)\end{array}$ \\
\hline
\end{tabular}

Of course, these expenditures take place with a lag, such that a time decomposition would yield a dip in GDP during the mandatory closure, followed by an upswing during reopening, and then even a level of GDP above baseline at the final sub-period of the time-horizon (see Fig. 1 in Appendix 7).

Note also some of the limitations of our analysis, especially due to potential structural changes in the economy, including many business failures and slow replacements. These would likely exacerbate the net losses and stretch out the recovery.

The employment impacts for this Scenario and the other two are presented in Table 10. The employment decline of $23.3 \%$ in the U.S. represents a decline in demand of 36.5 million workers, as reduced production from the mandatory closures and their indirect effects leads to a reduction in demand for labor. The employment impacts are slightly greater in percentage terms than the GDP impacts because service sectors, which are an important part of U.S. nonessential production, are much more negatively impacted than agriculture, processed food, and other essential manufacturing, and a large share of U.S. workers are employed in the former. In China and the ROW, non-essential businesses are less important to the economy and employ a much smaller portion of the workforce. Note also that employment increases due to Pent-up Demand are of a higher percentage than their counterpart GDP increases, thereby offsetting the Mandatory Closure employment declines slightly more strongly than is the case for GDP.

The GDP impacts of Scenario 2 are presented in the second partition of Table 9. Overall, the total impact on the U.S. economy is a $\$ 3.9$ trillion, or $18 \%$, decline in GDP. The percentage results are more than 2.5 times higher in the U.S. than in China and about $33 \%$ higher than in ROW. As in the U.S., the larger negative impacts on the ROW reflect the more gradual Reopenings of their economies, while in China the greater losses are due to indirect effects of COVID-19 on the world and hence trade. 
Table 10 Employment impacts (\% changes from baseline)

\begin{tabular}{|c|c|c|c|c|c|c|c|}
\hline $\begin{array}{l}\text { Country/ } \\
\text { Region }\end{array}$ & $\begin{array}{l}\text { Mandatory closure } \\
\text { \& reopening }\end{array}$ & Avoidance & $\begin{array}{l}\text { Communication } \\
\text { demand }\end{array}$ & $\begin{array}{l}\text { Deaths } \\
\text { and illness }\end{array}$ & $\begin{array}{l}\text { Health care } \\
\text { expenditure }\end{array}$ & $\begin{array}{l}\text { Pent-up } \\
\text { demand }\end{array}$ & $\begin{array}{l}\text { Total } \\
\text { impacts }\end{array}$ \\
\hline \multicolumn{8}{|c|}{ Scenario 1} \\
\hline USA & -23.3 & 0.3 & 1.2 & 0.0 & 0.2 & 6.9 & -14.7 \\
\hline China & -19.3 & 0.1 & 1.1 & 0.0 & 0.0 & 5.7 & -12.3 \\
\hline ROW & -23.9 & 0.0 & 1.3 & 0.0 & 0.0 & 6.8 & -15.7 \\
\hline \multicolumn{8}{|c|}{ Scenario 2} \\
\hline USA & -39.2 & -4.6 & 2.5 & 0.0 & 5.7 & 22.1 & -13.7 \\
\hline China & -38.7 & -5.2 & 2.6 & 0.0 & 6.0 & 22.4 & -13.0 \\
\hline ROW & -38.3 & -6.0 & 2.7 & -0.1 & 5.5 & 21.5 & -14.7 \\
\hline \multicolumn{8}{|c|}{ Scenario 3} \\
\hline USA & -58.4 & -3.6 & 2.8 & 0.1 & 1.4 & 33.8 & -23.8 \\
\hline China & -20.3 & -1.2 & 0.8 & 0.0 & 0.0 & 18.0 & -2.7 \\
\hline ROW & -47.2 & -3.0 & 3.9 & 0.0 & 0.2 & 32.6 & -13.6 \\
\hline
\end{tabular}

The major factor affecting the results is again Mandatory Closures and the phased Reopenings of businesses. These alone would have resulted in a $37.5 \%$ decrease in U.S. GDP, but again only about $40 \%$ of that amount in China because of the much shorter lock-down period in the latter. The results for ROW again fall about half-way in-between the other two regions.

Avoidance behavior impacts are significant in this case, amounting to an additional $\$ 853$ million of negative impacts on U.S. GDP, and adding a negative few percentage points to the impacts in all three regions. This reflects the assumption that the continuing increase in cases and deaths causes avoidance to continue even after businesses start to reopen. Communication demand in the U.S. is similar to Scenario 1, but about twice the size in the other two regions. GDP losses due to Death and Illness go up very slightly in all three regions, but their relatively small size compared to the labor force, coupled with decreased labor demand, make for relatively insignificant impacts on GDP. Health care costs go up and now have a sizable positive stimulating effect in all three regions. The reason for the larger impact of health care is that health care services now require the use of previously under-utilized resources, which allows production of Health Care Services to increase without a decline in the provision of other services. China also gains considerably as it increases exports of Health Care Services to the ROW, with the decline in exports from the U.S. Most importantly, Pent-up Demand triples in all three regions.

In Scenario 2, demand for workers declines by 39.2\% under the Mandatory Closures, reflecting the significant slow-down in the reopening of businesses in response to continued increases in COVID-19 cases and deaths. Since the same industries are closed or indirectly impacted in this and the previous scenario, this further decline in employment reflects the longer closure period and hence the longer these workers are not required, rather than an almost doubling of the unemployment rate. That said, the longer the mandatory closures remain in place the more likely the decline in demand for workers would increase unemployment, as firms can no longer keep under-employed workers on their payroll.

The GDP impacts of Scenario 3 are presented in the third partition in Table 9. Overall, the total impact on the U.S. economy is a $\$ 4.9$ trillion, or $23 \%$, decline in GDP. The percentage results are more than 3.5 times higher in the U.S. than in China and about 33\% higher than in ROW.

The major factor affecting the results is again Mandatory Closures and the slow Reopenings of businesses, which have both been extended in this scenario relative to Scenario 1. These alone would have resulted in a whopping $60.6 \%$ decrease in U.S. GDP, but again only about $40 \%$ of that amount in China because of the much shorter lock-down period in the latter. In 
this scenario, consumption of essentials in the U.S. and ROW cannot be maintained due to the significant decline in incomes. As a result, the percentage decline in GDP for the ROW is relatively larger since essentials are a more important part of this economy.

Avoidance Behavior impacts are only very slightly higher in this case than in Scenario 2, reflecting the fact that we assume extensive avoidance in both Scenarios 2 and 3. Communication Demand is about twice the size in percentage terms as Scenario 2. GDP losses due to Death and Illness are actually lower than in Scenario 2 in all three regions as unemployment rose more between Scenario 2 and 3 than the number of deaths, while between Scenarios 1 and 2, deaths rose more than unemployment. ${ }^{12}$ Gains from the increase in demand for Health care are also much lower than in Scenario 2, especially for China and ROW due to the decline in health care resulting from the mandatory closures and reopenings. As mentioned previously, in Scenario 3 people can no longer afford all of their baseline essential goods and services, including health care, due to the collapse in incomes and employment. This means that medical services for COVID-19 patients can now be met without resorting to excess capacity. ${ }^{13}$ Most importantly, the impact of Pent-up Demand more than doubles in all three regions vis-à-vis Scenario 2, consistent with our assumption that pent-up demand is extensive under this scenario.

We performed one sensitivity test, in addition to the 3 scenarios, which represent sensitivity tests in and of themselves. This was to vary the amount of telework potential in the face of the pandemic. We adjusted our base estimates with data from Dingel and Neiman (2020) and Dey et al. (2020), which amounted to an increase of telework potential by $25 \%$ to $100 \%$ and a decrease of telework potential by $50 \%$ to $75 \%$ (depending on the sector) for our mid-range scenario, Scenario 2 . The base case called for a $37.5 \%$ decrease in GDP due to mandatory closures, and the lower-bound estimate for telework is projected to increase this to $39.1 \%$, while the upper-bound estimate for telework is projected to decrease this to $34.7 \%$. The reason for the relatively small changes in reference to the base case is primarily due to the large indirect effects of the mandatory closure of a few key sectors in the economy that drive the results. One of these key sectors is construction, which is not significantly impacted by the ability to telework, since construction workers themselves are unable to telework. Another is recreational services, which is impacted to some extent by telework, but the impact is not sufficient to impact the overall results significantly.

\section{Interpretation and Policy Implications}

Our results should be considered upper-bound estimates due to the exclusion of countervailing policies. In addition, we have assumed that reductions in business output are accompanied by reductions in wages and salaries paid as people become unemployed, though some businesses will continue paying their employees. We have also omitted the spending of the small percentage of teleworkers who will continue to be employed in non-essential sectors, primarily as office staff. ${ }^{14}$

\footnotetext{
12 The number of deaths in Scenarios 2 and 3 are 1.25 and 1.75 million, respectively. Between Scenarios 1 and 2 deaths increased considerably and at a greater rate than unemployment, while in Scenario 3, unemployment grew at a faster rate. In Scenario 2, the deaths had an impact on the labor force, while in Scenario 3, the unemployment exceeded the deaths again.

${ }^{13}$ Using excess capacity in Scenario 2 is like reducing unemployment, which gives a big boost to employment and incomes.

${ }^{14}$ For sectors that an output cannot be produced by telecommuting (e.g., most manufacturing), we assume that they produce no products for the supply chain, and hence such sectors are modeled as a complete shutdown. It is possible that a proportion of the "output" of these sectors can continue in the form of administrative/clerical work. However, we did not model this as injections to the spending streams in the simulations.
} 
Finally, we have omitted some sources of business resilience, such as the use of inventories, relocation and the internet to continue to help produce goods and services (Rose 2017; Dormady et al. 2019).

We have collected empirical data on shutdown durations across the states in the U.S. We try to use the three scenarios to cover alternative assumptions in terms of the duration of the reopening process (e.g., Scenario 2 assumes a longer re-opening duration, which factors in the potential reverse of the reopening process because of the new surge of cases that were happening over the summer in a number of states in the U.S.) and the potential second-wave of large-scale closures (in Scenario 3) if there is another winter outbreak that coincides with the flu season. In addition, when the shocks are specified, both the length of the closures and portion of the sectors affected are taken into account to provide the portion of annual production that disappears. It is worth noting that, regardless of whether these declines occurred during the reopening, a second closure (or other types of restrictions on activity) does not affect the bottom-line impacts as long as they occurred in that period. Therefore, the scenarios considered capture many more permutations of mandatory closures and reopenings than appear to be recognized.

The timing of the vaccine is crucial and completely independent of the other issues being examined. To make the analysis manageable, we have linked the availability of the vaccine with the timing of plateauing of new cases. To fully examine the impact of the timing of the vaccine, we would need to do a full set of simulations where all other interventions were equal and only the timing differed. Since the timing of the vaccine is clearly something that would put an end to the need for mandatory closures and avoidance behavior, we felt that it was best not to focus on vaccines in this way, but rather to allow our other assumptions to run their course, so that we could see the full extent of their implications on the economy.

We also acknowledge the limitations of our model and its application, as well as of our assessment on how they bear on the results. As is the case in most GTAP-based analysis, we assume that, with the exception of factor markets, all other markets clear and firms are perfectly competitive. In addition to unemployment, factors of production are also assumed to be immobile across sectors, consistent with this paper focusing on very short-run impacts of the pandemic. Our results also rely on the estimated elasticities taken from the literature and used in the GTAP database. We conduct sensitivity analyses on some of our assumptions regarding investment and the trade balance, as well as our assumption that real consumption of essential goods and services will be maintained in the aggregate. Fixing the trade balance causes the losses in China, and to a lesser extent the ROW, to be much larger than when capital flows were endogenous. This reflects the fact that with the trade balance fixed, U.S. savings must remain in the U.S. With less investment moving to China, China's GDP declines by about the same amount as the U.S. decline, despite mandatory closures only being in place for 6 weeks. In the U.S., increased demand for investment goods raises the potential for increased production, but with businesses closed that increase in demand cannot translate into an increase in GDP and hence prices rise. Our assumptions regarding real consumption of essentials ensures that consumers continue to purchase and firms continue to produce essential goods and services, despite declining incomes and the closure of non-essential businesses, although our sensitivity tests indicate that it has only a small impact on the macroeconomic impacts in the U.S. We do find that the loses for the ROW rise when consumption of essentials is not fixed. This is consistent with our other results and data that show that the ROW is more heavily reliant on the production of essentials.

Finally, we summarize our results in comparison to other studies that have examined the impact of COVID-19 under various conditions. Several studies, including one by the authors of this paper, have focused on the impacts of mandatory closures and generally found the impacts on GDP to be in the range of 20 to $25 \%$ for scenarios similar to those that actually took place (see del Rio-Chanona et al. 2020; Mandel and Veetil 2020; OECD 2020; Walmsley et al. 2020). Dixon 
et al. (2020), using a quarterly CGE model, have explored the macroeconomic impacts of COVID-19 in relation to several drivers over a two-year time horizon. They estimated a 19\% reduction in GDP at the trough of the economic downturn at the end of the first quarter of 2020 and a $12 \%$ decline by the end of the second quarter. They have incorporated our estimates of telework, and also include government expenditures on health care and some countervailing fiscal policies, such as unemployment compensation and tax relief, all of which dampen the negative impacts. CBO (2020) estimates that Real GDP will contract by $11 \%$ in the second quarter of this year, resulting in the number of people employed being almost 26 million lower than the number in the fourth quarter of 2019. If this rate were to continue, the decline in U.S. Real GDP for the year would be up to $38 \%$ on an annual basis; however, given the reopenings the overall annual decline is projected to drop to $5.4 \%$. Our results fall in-between these extreme bounds.

Additional insight into the severity of COVID-19 in the U.S. can be obtained by comparing the impacts projected here with those of other major disasters. Zandi et al. (2017 estimate the following GDP impacts, which we've have converted to 2019 dollars): SuperStorm Sandy of 2012 (\$27.3 billion), Hurricane Katrina of 2005 (\$32.2 billion), Northridge Earthquake of 1995 (\$16.4 billion), and Midwest Floods of 1993 (\$12.3 billion). ${ }^{15}$ In terms of other disasters, Rose and Blomberg (2010) summarize the GDP impacts of five studies, including their own, of the 2001 World Trade Center Attacks as ranging from $\$ 70$ to $\$ 136$ billion. Most revealing is that our projections of GDP impacts even exceed those for the Great Recession. Adapting figures provided by Christiano (2017), the Great Recession GDP impacts over the five years until its recovery are on the order of $\$ 2.8$ trillion. However, these figures include the dampening offsetting effect of very strong countervailing policies, while ours omit them. However, even factoring in various stimulus packages, would likely not reduce our upperbound estimates to be lower than $\$ 2.8$ trillion.

Our analysis leads to several important insights and policy implications:

- Mandatory closures do have a severe impact on the world economy and employment, and in particular the production of non-essential goods and services. Scenario 3, however, shows that, if the pandemic requires a prolonged shutdown or continued partial closure of non-essential services, then the outcome for economic well-being in terms of essential and non-essential consumption and production could be devastating.

- While China may have been able to avoid the severe repercussions of the virus itself, it cannot avoid the negative impacts of the decline in production and trade in the rest of the world on global supply chains. As indicated in the sensitivity analysis discussion, these losses could be even larger if excess savings does not flow into China.

- The impact of additional avoidance behaviors following the reopening of the economy were also found to be considerable. The impact of any avoidance behavior that occurred during the mandatory closure period is included as part of the mandatory closure effect. Hence, the impact of all avoidance behavior due to the pandemic is likely to be a multiple of these effects. Further analysis of the full extent of these avoidance behaviors, especially during the lockdown period, is necessary to examine the true cost of the mandatory closures.

- The analysis of the increase in demand for health care clearly demonstrates the tradeoffs that will need to be made in this sector. The inclusion of excess capacity in the health care sector was essential to ensuring that this sector could respond to the increase in demand, as

\footnotetext{
${ }^{15}$ Note these estimates are rather conservative. For example, Hallegate (2008) estimates the GDP impacts of Hurricane Katrina over the several years until recovery at $\$ 192$ billion in 2019 dollars.
} 
well as the ability of the sector to delay other procedures. In Scenario 3, the excess capacity was insufficient. It was only the substantial decline in incomes and demand for essential goods that allowed the health care sector to meet the increase in demand, but the cost in terms of other health care services was significant.

- Finally, pent-up demand is an important factor to consider in our ability to recover from this severe downturn. We can only hope that those who are accumulating savings will spend those and help boost the economy once the pandemic is over.

\section{Conclusion}

In this study, we have used a state-of-the-art, static computable general equilibrium model to simulate three COVID-19 scenarios that range from a relatively moderate pandemic to an extensive pandemic. The net U.S. GDP losses from COVID-19 are estimated to range from $\$ 3.2$ trillion (14.8\%) to $\$ 4.8$ trillion $(23.0 \%)$ in a 2-year period for the three scenarios. The employment decline is estimated to range from $14.7 \%$ to $23.8 \%$. Note that the effect of Mandatory Closures is still sizable even after we have made a resilience adjustment for telework.

The major factor affecting the results in all three scenarios is the combination of Mandatory Closures and Partial Reopenings of businesses. These alone would have resulted in a $22.3 \%$ to $60.6 \%$ decrease in the U.S. GDP and a $23.3 \%$ to $58.4 \%$ decline of employment across the scenarios. U.S. impacts are estimated to be higher than those for China and the ROW in percentage terms because: 1) a higher proportion of the U.S. economy is impacted by the mandatory closures, 2) the U.S. has a relatively longer duration of mandatory closures, and 3) the U.S. produces and exports a higher share of non-essential goods and services.

The impacts of people's avoidance behavior are almost imperceptible in the moderate and declining scenario (Scenario 1). However, they become significant, causing about $\$ 850$ to $\$ 900$ billion U.S. GDP losses in the more severe scenarios.

Pent-up Demand is the second most influential factor and offsets the negative impacts of Closures/Reopenings by about $30 \%$ for all three regions in the moderate and declining scenario and up to $60 \%$ to $85 \%$ in the extensive pandemic scenario.

Both increased Communication Demand because of telecommuting and increased expenditure on Health Care result in positive offset effects in all three regions. The positive effects of the former increase as the Mandatory Closures and Partial Reopenings last longer. The Health Care expenditures only have a sizable positive stimulating effect in the second severe pandemic scenario (Scenario 2) because it is accompanied by a large increase in the utilization of excess capacity. In Scenario 3, the most severe pandemic scenario, on the other hand, it is accompanied by a significant fall in the provision of other health care services due to the collapse in incomes and ensuing reduced demand for essential goods and services, including health services for more standard needs.

Acknowledgements The authors wish to thank Scott Farrow, Richard John, and Aaron Strong for their helpful comments on an earlier version of the report that focused on mandatory closures, as well as Juan Machado, Konstantinos Papaefthymiou, and Adam Einbinder for their valuable research assistance. The authors are, however, responsible for any remaining errors or omissions.

Funding This material is based upon work supported by the U.S. Department of Homeland Security Center for Accelerating Operational Efficiency (CAOE) under Grant Award Number 17STQAC00001-03-00. The views and conclusions contained in this document are those of the authors and should not be interpreted as necessarily 
representing the institutions with which the authors are affiliated nor the official policies, either expressed or implied, of the U.S. Department of Homeland Security.

\section{Compliance with Ethical Standards}

Conflict of Interest The authors declare no potential conflicts of interest with respect to the research, authorship and/or publication of this article.

\section{Appendices $^{16}$}

\section{Appendix 1}

\section{Additional Data Used in COVID-19 Health Outcome Calculation}

Appendix Table 11 presents a summary of estimated percentages of people that were hospitalized, admitted to ICU, and died because of coronavirus infection with respect to the total number of confirmed cases based on the data gathered from several studies.

Appendix Table 12 summarized the projections on cumulative COVID-19 deaths in the U.S. provided by 10 models that are cited in the CDC COVID-19 Forecasts website. The data collected in the Appendix Table 11 were model projections as of May 15, 2020.

We further estimated the projected cumulative numbers of hospitalization, ICU admissions, and deaths by age group in Appendix Table 13. An additional piece of information we used in this calculation is the distribution of COVID-19 deaths among different age groups. The data presented in the first numerical column in Appendix Table 13 are collected from the CDC Provisional Death Counts for Coronavirus Disease by age group (CDC 2020e). In the last three columns, we estimated the number of deaths in the three age groups for the May 30, June 6, and August 4 projections, respectively.

Next, based on the relationship between the death rate and the hospitalization rate for different age groups presented in Table 1 and the number of deaths in each age group (presented in Appendix Table 13), we estimated the projected cumulative number of hospitalizations, ICU admissions, and deaths for May 30, June 6, and August 4 in Appendix Table 14. The number of coronavirus patients who received outpatient medical treatment is calculated as the difference between the total number of cases and sum of hospitalization (survived) and fatality.

\section{Appendix 2}

\section{Additional Data Used in Workday Losses Calculation}

Based on a small sample of COVID-19 patients with critical conditions in the Seattle region, a study found that the median length of ICU stay of survivors was 14 days (IQR 4-17). The median length of total hospital stay of the survivors that were admitted in ICU was 17 days (IQR 16-23) (Bhatraju et al. 2020).

\footnotetext{
$\overline{16}$ The Appendices are co-authored by Juan Machado, Dan Wei, Terrie Walmsley, and Adam Einbinder.
} 


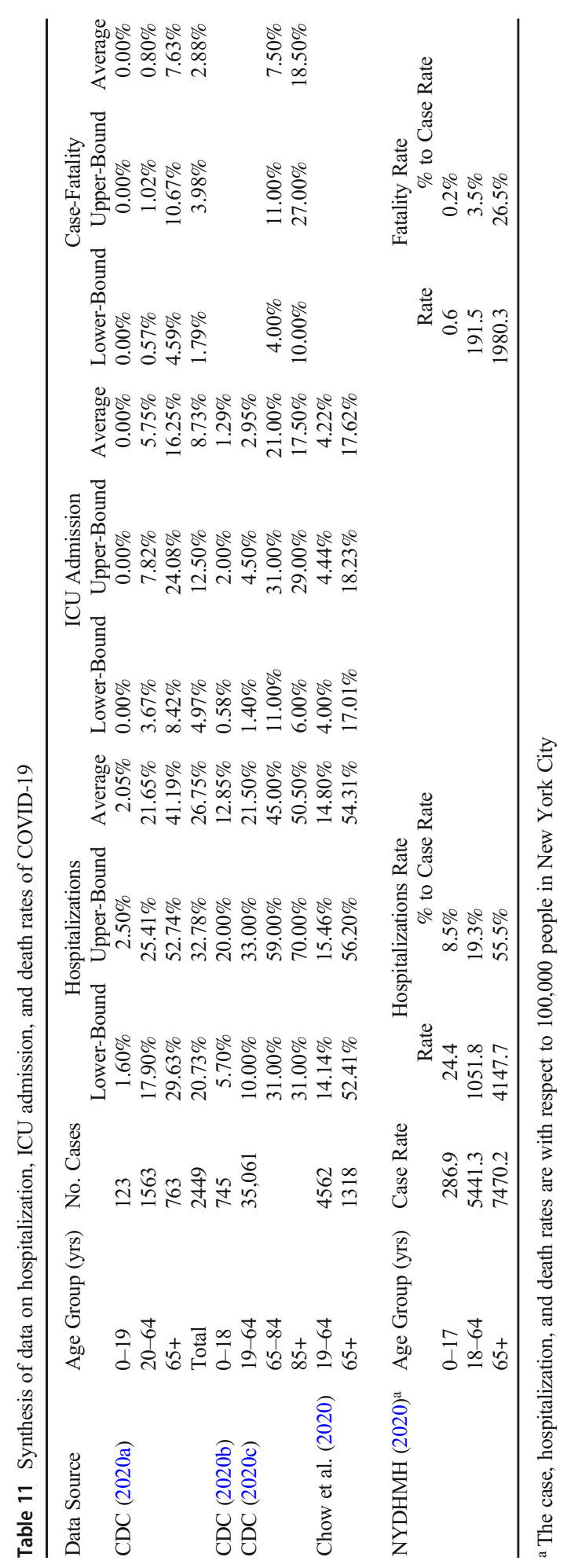


Table 12 Projections of cumulative COVID-19 deaths in the U.S

\begin{tabular}{|c|c|c|c|c|c|c|c|c|c|}
\hline \multirow[t]{2}{*}{ Forecast model } & \multicolumn{3}{|c|}{ through May 30} & \multicolumn{3}{|c|}{ through June 6} & \multicolumn{3}{|c|}{ through August 4} \\
\hline & $\begin{array}{l}\text { Lower- } \\
\text { bound }\end{array}$ & Mean & $\begin{array}{l}\text { Upper- } \\
\text { bound }\end{array}$ & $\begin{array}{l}\text { Lower- } \\
\text { bound }\end{array}$ & Mean & $\begin{array}{l}\text { Upper- } \\
\text { bound }\end{array}$ & $\begin{array}{l}\text { Lower- } \\
\text { bound }\end{array}$ & Mean & $\begin{array}{l}\text { Upper- } \\
\text { bound }\end{array}$ \\
\hline $\begin{array}{l}\text { Columbia U. ( } 20 \% \\
\text { contact reduction) }\end{array}$ & 99,092 & 106,425 & 118,577 & 104,687 & 116,748 & 137,401 & & & \\
\hline IHME & 102,712 & 111,473 & 127,868 & 106,827 & 119,799 & 145,148 & 113,182 & 147,040 & 226,971 \\
\hline MOBS & 79,920 & 100,454 & 125,306 & 84,361 & 106,665 & 141,957 & & & \\
\hline LANL & 87,367 & 99,444 & 120,942 & 176,263 & 208,211 & 286,762 & & & \\
\hline UT Austin & 101,581 & 105,682 & 111,358 & 104,192 & 109,728 & 117,743 & & & \\
\hline YYG & 97,704 & 107,636 & 119,648 & 101,262 & 116,086 & 134,486 & 116,350 & 190,016 & 321,484 \\
\hline MIT & 109,508 & 111,885 & 114,262 & 117,638 & 120,192 & 122,746 & & & \\
\hline UCLA & 97,128 & 104,724 & 113,246 & 101,204 & 110,695 & 121,476 & & & \\
\hline GA Tech & 98,567 & 105,479 & 112,665 & 149,098 & 158,364 & 173,858 & & & \\
\hline Average & 97,064 & 105,911 & 118,208 & 116,170 & 129,610 & 153,509 & 114,766 & 168,528 & 274,228 \\
\hline
\end{tabular}

Source: CDC (2020d)

Among the 305 adults hospitalized with COVID-19 in Georgia, for patients admitted in ICU, the median ICU duration was 8 days (IQR 5-12). Patients older than 65 have a slightly longer median ICU stay. For all the hospitalized patients, the median duration of hospital stay was 8.5 days (IQR 5-14) (Gold et al. 2020).

In response to the increased demand for hospital services, CDC released an Excel spreadsheet-based tool, COVID19Surge, to help hospital administrators evaluate the impact of COVID-19 on hospital capacity and resource utilization. The default assumptions of average length of hospital stays adopted in the tool are 8 days for Non-ICU patients, 10 days for ICU patients without the use of ventilator, and 16 days for ICU patients that required ventilator (CDC 2020f).

Among the 5139 patients confirmed with COVID-19 who received critical care treatment in $\mathrm{UK}$, the median length of stay in critical care is 6 and 7 days for survivors and non-survivors, with IQR of 3 to 13 and 4 to 13, respectively. Patients that received advanced respiratory support or renal support have longer median length of stay (13 [7-19] vs. 16 [9-23] days for survivors and 8 [5-13] vs. 10 [6-15] days for non-survivors) (ICNARC 2020). Note that all the durations of stays reported in this study are the lengths of stay in ICU, not the total duration of hospitalization.

Table 13 Projections of cumulative COVID-19 deaths by age group

\begin{tabular}{|c|c|c|c|c|c|}
\hline \multirow[t]{2}{*}{ Age group (yrs) } & \multicolumn{2}{|c|}{ COVID-19 deaths $(2 / 1 \text { to } 5 / 9)^{\mathrm{a}}$} & \multirow[t]{2}{*}{ through May 30} & \multirow[t]{2}{*}{ through June 6} & \multirow[t]{2}{*}{ through Aug 4} \\
\hline & Number & $\%$ & & & \\
\hline $0-18$ & 41 & $0.1 \%$ & 79 & 97 & 126 \\
\hline $19-64$ & 10,888 & $19.8 \%$ & 21,020 & 25,723 & 33,447 \\
\hline $65+$ & 43,932 & $80.1 \%$ & 84,812 & 103,790 & 134,955 \\
\hline Total & 54,861 & $100.0 \%$ & 105,911 & 129,610 & 168,528 \\
\hline
\end{tabular}

a Data during this period are incomplete because of the lag in time between when the death occurred and when the death certificate is completed, submitted to NCHS and processed for reporting purposes. This delay can range from 1 week to 8 weeks or more, depending on the jurisdiction, age, and cause of death 
Table 14 Health outcome estimates (number of people)

\begin{tabular}{|c|c|c|c|c|c|c|}
\hline \multicolumn{7}{|c|}{ May 30 Forecast } \\
\hline $\begin{array}{l}\text { Age } \\
\text { Group } \\
\text { (yrs) }\end{array}$ & $\begin{array}{l}\text { Total } \\
\text { Confirmed } \\
\text { Cases }\end{array}$ & $\begin{array}{l}\text { Outpatient } \\
\text { Medical } \\
\text { Treatment }\end{array}$ & $\begin{array}{l}\text { Total } \\
\text { Hospitalizations }\end{array}$ & $\begin{array}{c}\text { Hospitalizations } \\
\text { Non ICU }\end{array}$ & $\begin{array}{l}\text { Hospitalizations } \\
\text { ICU }\end{array}$ & Fatality \\
\hline $0-18$ & 39,500 & 36,619 & 3054 & 2802 & 252 & 79 \\
\hline $19-64$ & 973,148 & 805,817 & 188,271 & 146,311 & 41,960 & 21,020 \\
\hline $65-84$ & 788,949 & 501,188 & 310,284 & 202,949 & 107,335 & 84,812 \\
\hline Total & $1,801,597$ & $1,343,624$ & 501,608 & 352,061 & 149,547 & 105,911 \\
\hline \multicolumn{7}{|c|}{ June 6 Forecast } \\
\hline $\begin{array}{l}\text { Age } \\
\text { Group } \\
\text { (yrs) }\end{array}$ & $\begin{array}{l}\text { Total } \\
\text { Confirmed } \\
\text { Cases }\end{array}$ & $\begin{array}{l}\text { Outpatient } \\
\text { Medical } \\
\text { Treatment }\end{array}$ & $\begin{array}{l}\text { Total } \\
\text { Hospitalizations }\end{array}$ & $\begin{array}{c}\text { Hospitalizations } \\
\text { Non ICU }\end{array}$ & $\begin{array}{l}\text { Hospitalizations } \\
\text { ICU }\end{array}$ & Fatality \\
\hline $0-18$ & 48,500 & 44,975 & 3737 & 3428 & 309 & 97 \\
\hline $19-64$ & $1,190,880$ & 986,108 & 230,398 & 179,049 & 51,348 & 25,723 \\
\hline $65-84$ & 965,488 & 613,338 & 379,712 & 248,360 & 131,352 & 103,790 \\
\hline Total & $2,204,868$ & $1,644,421$ & 613,847 & 430,838 & 183,009 & 129,610 \\
\hline \multicolumn{7}{|c|}{ August 5 Forecast } \\
\hline $\begin{array}{l}\text { Age } \\
\text { Group } \\
\text { (yrs) }\end{array}$ & $\begin{array}{l}\text { Total } \\
\text { Confirmed } \\
\text { Cases }\end{array}$ & $\begin{array}{l}\text { Outpatient } \\
\text { Medical } \\
\text { Treatment }\end{array}$ & $\begin{array}{l}\text { Total } \\
\text { Hospitalizations }\end{array}$ & $\begin{array}{c}\text { Hospitalizations } \\
\text { Non ICU }\end{array}$ & $\begin{array}{l}\text { Hospitalizations } \\
\text { ICU }\end{array}$ & Fatality \\
\hline $0-18$ & 63,000 & 58,416 & 4859 & 4458 & 402 & 126 \\
\hline $19-64$ & $1,548,472$ & $1,282,212$ & 299,580 & 232,813 & 66,767 & 33,447 \\
\hline $65-84$ & $1,255,395$ & 797,504 & 493,729 & 322,936 & 170,794 & 134,955 \\
\hline Total & $2,866,868$ & $2,138,133$ & 798,168 & 560,206 & 237,962 & 168,528 \\
\hline
\end{tabular}

Another study, which focused on 249 COVID-19 patients in Shanghai, China, estimated a median duration of onset of symptoms to hospitalization of 4 days (IQR 2-7). The median hospitalization duration was 16 (IQR 12-20) days. Patients who were admitted in ICU had a significantly longer median length of fever compared to those who were not treated in ICU ( 31 days vs. 9 days after the onset of symptoms). The median length to have viral clearance in the upper respiratory route after onset of symptoms was 10 days for non-ICU patients and 22 days for ICU patients (Chen et al. 2020).

For a cohort of 77 COVID-19 patients in Beijing, a study found that the median hospitalization duration for all patients was 13 days (IQR 10-18). The hospitalization duration was 12 days (IQR 10-16) and 18.5 days (IQR 15-21) for non-severe and severe patients, respectively. The median time of illness onset to hospital discharge for all patients was 18.5 days (IQR 12-22), and was 18 days (IQR 15-21) and 24.5 days (IQR 22-27) for nonsevere and severe patients, respectively (Zhao et al. 2020).

Appendix Table 15 summarizes the length of illness onset to hospitalization as well as length of hospital stay for both non-severe and severe cases from the above reviewed studies.

Based on the data presented in Appendix Table 15, we assume that the average hospital stays for non-severe and severe (ICU admitted) COVID-19 patients are 10 days and 15.5 days, respectively. The average length from illness onset to hospitalization is 4.5 days. If we further assume that there will be an additional 3 days for non-severe patients and 5 days for severe patients to fully recover before they can return to work after hospital discharge, the total productivity losses are 17.5 days for non-severe patients and 25 days for severe patients. Appendix Table 16 presents the per-person lost productivity in days for different categories of health outcome. 
Table 15 Length from illness onset to hospitalization and duration of hospital stay

\begin{tabular}{|c|c|c|c|c|c|}
\hline \multirow[t]{2}{*}{ Data source } & \multirow{2}{*}{$\begin{array}{l}\text { Study Country/ } \\
\text { Region }\end{array}$} & \multirow{2}{*}{$\begin{array}{l}\text { From illness onset to } \\
\text { Hospitalization (days) }\end{array}$} & \multirow{2}{*}{$\begin{array}{l}\text { Non-severe } \\
\text { cases } \\
\text { Entire Hospital } \\
\text { Stay (days) }\end{array}$} & \multicolumn{2}{|c|}{ Severe cases } \\
\hline & & & & $\begin{array}{l}\text { ICU Stay } \\
\text { (days) }\end{array}$ & $\begin{array}{l}\text { Entire Hospital } \\
\text { Stay (days) }\end{array}$ \\
\hline Bhatraju et al. (2020) & Seattle & & & 14 & 17 \\
\hline Gold et al. (2020) & Geogria & & & 8 & $11^{\mathrm{a}}$ \\
\hline CDC (2020a, b, c, d, e, f) & US & & 8 & 10 to 16 & 13 to $19^{\text {a }}$ \\
\hline ICNARC (2020) & UK & & & 7 to 16 & $10-19^{\text {a }}$ \\
\hline Chen et al. (2020) & $\begin{array}{c}\text { Shanghai, } \\
\text { China }\end{array}$ & 4 & & & \\
\hline Zhao et al. (2020) & Beijing, China & 5.5 & 12 & & 18.5 \\
\hline
\end{tabular}

a Assume the entire hospital stay is 3 days longer than the length of ICU stay based on Bhatraju et al. (2020)

Table 16 Patient lost productivity (days)

\begin{tabular}{lllll}
\hline & Outpatient medical treatment & Hospitalization non-ICU & Hospitalization ICU & Fatalities \\
\hline $0-17$ & 1.5 & 17.5 & 25 & 125 \\
$18-64$ & 1.9 & & & \\
$65+$ & 5.3 & & & \\
\hline
\end{tabular}

To calculate the lost productivity due to caring for sick family members, the following assumptions are adopted:

For sick children: 1) for any day that the children are sick at home, one full workday is lost for the caring parent; and 2) for any day that the children are hospitalized, half workday of the caring parent is lost. We also adjust the workday losses down according to the percentage of families with children that have no parent that is not employed. Based on the U.S. Census Bureau data, this percentage is $75.5 \%$ in 2019 (U.S. Census 2020a). ${ }^{17}$

When we calculate the workday losses due to the care of sick spouses, we first apply the percentage of total population married with spouse present. This percentage is $48.9 \%$ in 2019 (U.S. Census 2019). We next assume that $50 \%$ of working people with spouses will decide to take sick days to care for their sick spouses during their illness. We further assume that: 1) for any sick day due to outpatient medical treatment, half workday of the caring spouse is lost; 2) for any day that is lost because of hospitalization, half workday of the caring spouse is lost.

When we calculate the workday losses due to the care of sick elderly family members, we first assume that $35.3 \%$ of those patients will receive care from their family members. This is based on the data presented in the Caregiving in the U.S. 2020 report, which indicated that about 53 million adult Americans provided unpaid family care for someone 50+ years of age over the last 5 years (NAC 2020). This represents $35.3 \%$ of the $50+$ population (U.S. Census 2020b). We also use the labor force participation rate to get the percentage of unpaid family caregivers that are in the labor force. We then further assume that: 1) for any sick day due to outpatient medical treatment of people in the 65+ age group, half workday of the caring family

\footnotetext{
${ }^{17}$ There were 33,399 thousand families with own children, of which there were 14,661 thousand married-couple families with both parents employed, 7914 thousand families maintained by mother with employment, and 2631 thousand families maintained by father with employment (U.S. Census 2020a).
} 
member is lost; 2) for any day that is lost because of hospitalization, half workday of the caring family member is lost.

\section{Appendix 3}

\section{Estimation of Direct Output Impacts by Sector for Mandatory Closures and Reopening}

Appendix Table 17 summaries the mandatory shutdown and "stay-at-home" orders implemented in individual states between March and June in the U.S. Information is presented for the order declared date, order expiration date, and the length (days) of the order.

Appendix Table 18 presents the percentage reduction in U.S. annual GDP by sector due to mandatory closures for the three scenarios analyzed in this study. The telework potentials by sector (presented in Appendix Table 19) are factored in when we estimate the percentage direct production declines for non-essential sectors that are affected by the mandatory closure order.

We note that more resilience in the Education sector has taken place than we have taken into account. We acknowledge this as a limitation of our analysis. Our sensitivity analysis on higher telework potentials sheds light on the impacts of increased flexibility in several sectors, including Education, but indicate that this flexibility does not alter the impact much.

The detailed reopening stages and timelines of five major states (California, Texas, New York, Illinois, and Florida) according to the reopening plans released by these states by the end of May are summarized in Appendix Table 20.

Appendix Table 21 presents the percentage reduction in U.S. annual GDP by sector due to the phased-in reopening process for each of the three scenarios.

\section{Appendix 4}

\section{Summary of Survey Data on Avoidance Behavior}

This Appendix summarizes findings from public opinion surveys around avoidance behavior in response to COVID-19 pandemic. The first section summarizes avoidance behavior trends before states implemented shutdown orders. The second section focuses on people's willingness to resume activities after their state lifts shutdown orders, or when they believe it would be safe to resume certain activities. In the third section, we present the assumptions we will use in the economic impact analysis regarding each type of avoidance behavior. These assumptions are based on a synthesis of the literature that is summarized in detail in the first two sections.

\section{Avoidance Behavior at the Beginning of the Shutdown Orders}

We reviewed 11 most recent public opinion polls that asked U.S. adults questions related to avoidance behavior resulting from the coronavirus. All polls surveyed respondents before the announcement of shelter-in-place rules in California and New York and the results therefore mostly represent voluntary avoidance efforts. Below, we synthesize the adoption of avoidance 
Table 17 Stay-at-home orders and mandatory closures by U.S. State (March to June 2020)

\begin{tabular}{|c|c|c|c|c|}
\hline State & Order declared & $\begin{array}{l}\text { Order expired or } \\
\text { reopening } \\
\text { started }\end{array}$ & $\begin{array}{l}\text { Length } \\
\text { (days) } \\
\text { of Closure }\end{array}$ & Note \\
\hline Alabama & 3-Apr & 30-Apr & 27 & \\
\hline Alaska & 28-Mar & 24-Apr & 27 & \\
\hline Arizona & 30-Mar & 15-May & 46 & \\
\hline Arkansas & & & & $\begin{array}{l}\text { Did not have a statewide stay-at-home } \\
\text { order, but some business restrictions } \\
\text { lifted starting May } 6\end{array}$ \\
\hline California & 19-Mar & 12-May & 54 & $\begin{array}{l}\text { Starting May } 12 \text {, restaurants and } \\
\text { shopping centers can open in } \\
\text { counties that meet certain criteria }\end{array}$ \\
\hline Colorado & 26-Mar & 26-Apr & 31 & \\
\hline Connecticut & 23-Mar & 20-May & 58 & \\
\hline $\mathrm{DC}$ & 1-Apr & 8-Jun & 68 & \\
\hline Delaware & 24-Mar & 31-May & 68 & \\
\hline Florida & 3-Apr & 4-May & 31 & \\
\hline Georgia & 3-Apr & 30-Apr & 27 & \\
\hline Hawaii & 25-Mar & 7-May & 43 & $\begin{array}{l}\text { Order set to expire May } 31 \text { but } \\
\text { reopening started May } 7\end{array}$ \\
\hline Idaho & 25-Mar & 30-Apr & 36 & \\
\hline Illinois & 21-Mar & 31-May & 71 & \\
\hline Indiana & 25-Mar & 4-May & 40 & \\
\hline Iowa & & & & $\begin{array}{l}\text { Did not have a statewide stay-at-home } \\
\text { order, but loosened restrictions in } \\
\text { most counties starting May } 1\end{array}$ \\
\hline Kansas & 30-Mar & 3-May & 34 & \\
\hline Kentucky & 26-Mar & 20-May & 55 & \\
\hline Louisiana & 22-Mar & 15-May & 54 & \\
\hline Maine & 2-Apr & 11-May & 39 & $\begin{array}{l}\text { Stores (May 11) and restaurants } \\
\text { (May 18) will be allowed to reopen } \\
\text { in certain rural counties }\end{array}$ \\
\hline Maryland & 30-Mar & 15-May & 46 & \\
\hline Massachusetts & 24-Mar & 18-May & 55 & \\
\hline Michigan & 24-Mar & 28-May & 65 & \\
\hline Minnesota & 27-Mar & 17-May & 51 & \\
\hline Mississippi & 3-Apr & 27-Apr & 24 & \\
\hline Missouri & 6-Apr & 3-May & 27 & \\
\hline Montana & 26-Mar & 26-Apr & 31 & \\
\hline Nebraska & & & & $\begin{array}{l}\text { Did not have a statewide stay-at-home } \\
\text { order, but some business restrictions } \\
\text { lifted starting May } 4\end{array}$ \\
\hline Nevada & 1-Apr & 9-May & 38 & \\
\hline New Hampshire & 27-Mar & 11-May & 45 & $\begin{array}{l}\text { Order set to expire May } 31 \text { but } \\
\text { reopening started May } 11\end{array}$ \\
\hline New Jersey & 21-Mar & 5-Jun & 76 & \\
\hline New Mexico & 24-Mar & 16-May & 53 & $\begin{array}{l}\text { Retailers, offices and houses of worship } \\
\text { can open at limited capacities } \\
\text { beginning May } 16\end{array}$ \\
\hline New York & 22-Mar & 15-May & 54 & $\begin{array}{l}\text { Limited reopening in five regions } \\
\text { starting May } 15\end{array}$ \\
\hline North Carolina & 30-Mar & 8-May & 39 & $\begin{array}{l}\text { Order set to expire May } 31 \text { but } \\
\text { reopening started May } 8\end{array}$ \\
\hline North Dakota & & & & $\begin{array}{l}\text { Did not have a statewide stay-at-home } \\
\text { order, but some business restrictions } \\
\text { lifted starting May } 1\end{array}$ \\
\hline
\end{tabular}


Table 17 (continued)

\begin{tabular}{|c|c|c|c|c|}
\hline State & Order declared & $\begin{array}{l}\text { Order expired or } \\
\text { reopening } \\
\text { started }\end{array}$ & $\begin{array}{l}\text { Length } \\
\text { (days) } \\
\text { of Closure }\end{array}$ & Note \\
\hline Ohio & 23-Mar & 15-May & 53 & $\begin{array}{l}\text { Order set to expire May } 29 \text { but } \\
\text { reopening started May } 15\end{array}$ \\
\hline Oklahoma & & & & $\begin{array}{l}\text { Did not have a statewide stay-at-home } \\
\text { order, but some business restrictions } \\
\text { lifted starting April } 24\end{array}$ \\
\hline Oregon & 23-Mar & 15-May & 53 & Retail stores statewide to reopen on May 15 \\
\hline Pennsylvania & 1-Apr & 8-May & 37 & Counties to open in phases \\
\hline Rhode Island & 28-Mar & 8-May & 41 & \\
\hline South Carolina & 7-Apr & 4-May & 27 & $\begin{array}{l}\text { The reopening began with retail stores } \\
\text { around April } 20\end{array}$ \\
\hline South Dakota & & & & $\begin{array}{l}\text { Did not have a statewide stay-at-home } \\
\text { order, but state announced a "Back } \\
\text { to Normal" plan on April } 28\end{array}$ \\
\hline Tennessee & 1-Apr & 30-Apr & 29 & \\
\hline Texas & 2-Apr & 30-Apr & 28 & \\
\hline Utah & & & & $\begin{array}{l}\text { Did not have a statewide stay-at-home } \\
\text { order, but some business restrictions } \\
\text { lifted starting May } 1\end{array}$ \\
\hline Vermont & 24-Mar & 15-May & 52 & \\
\hline Virginia & 30-Mar & 15-May & 46 & $\begin{array}{l}\text { First phase of reopening starting } \\
\text { May } 15\end{array}$ \\
\hline Washington & 25-Mar & 11-May & 47 & $\begin{array}{l}\text { Small counties were approved for } \\
\text { partial reopenings }\end{array}$ \\
\hline West Virginia & 23-Mar & 3-May & 41 & \\
\hline Wisconsin & 24-Mar & 13-May & 50 & \\
\hline Wyoming & & & & $\begin{array}{l}\text { Did not have a statewide stay-at-home } \\
\text { order, but some business restrictions } \\
\text { lifted starting May } 1\end{array}$ \\
\hline
\end{tabular}




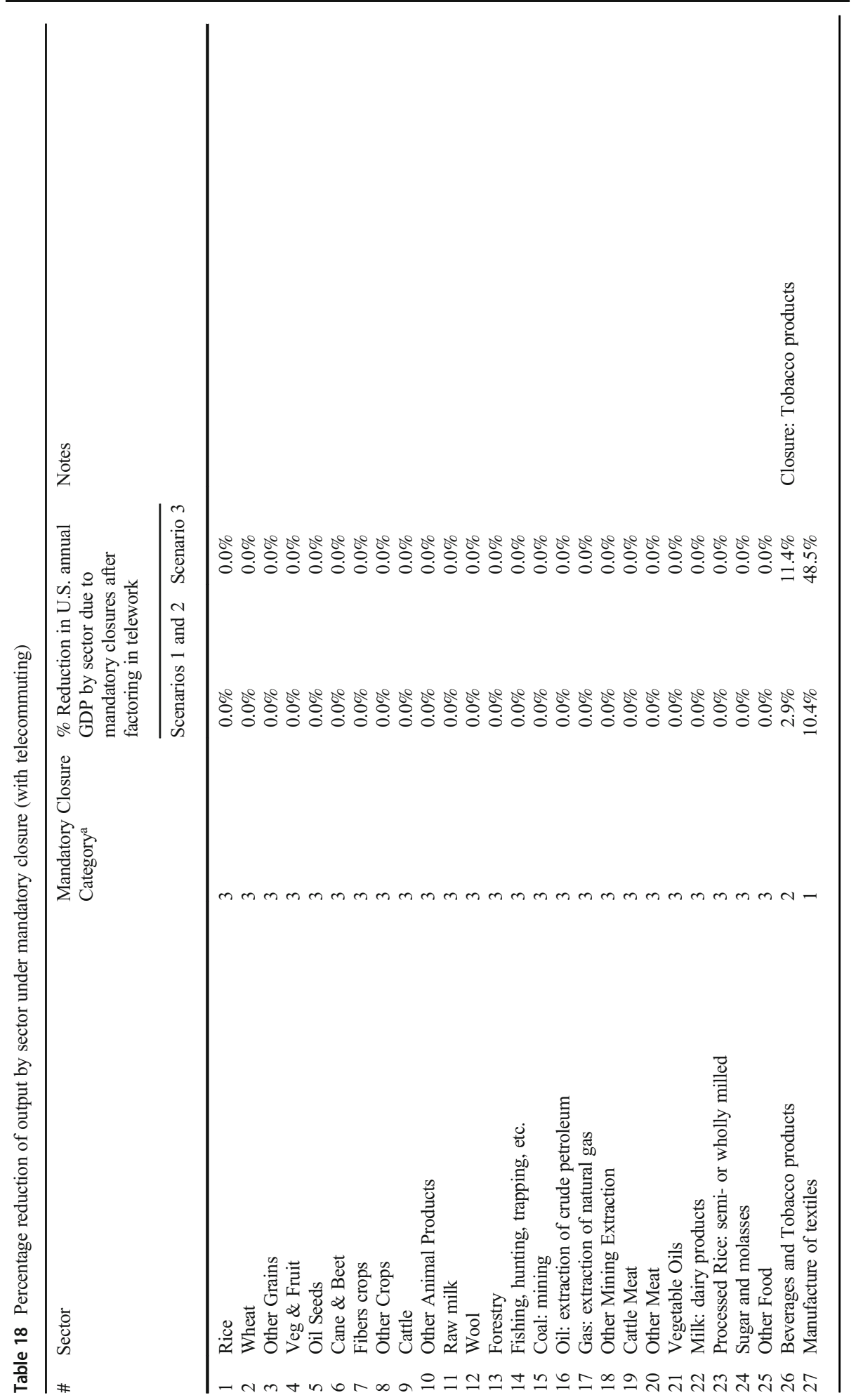




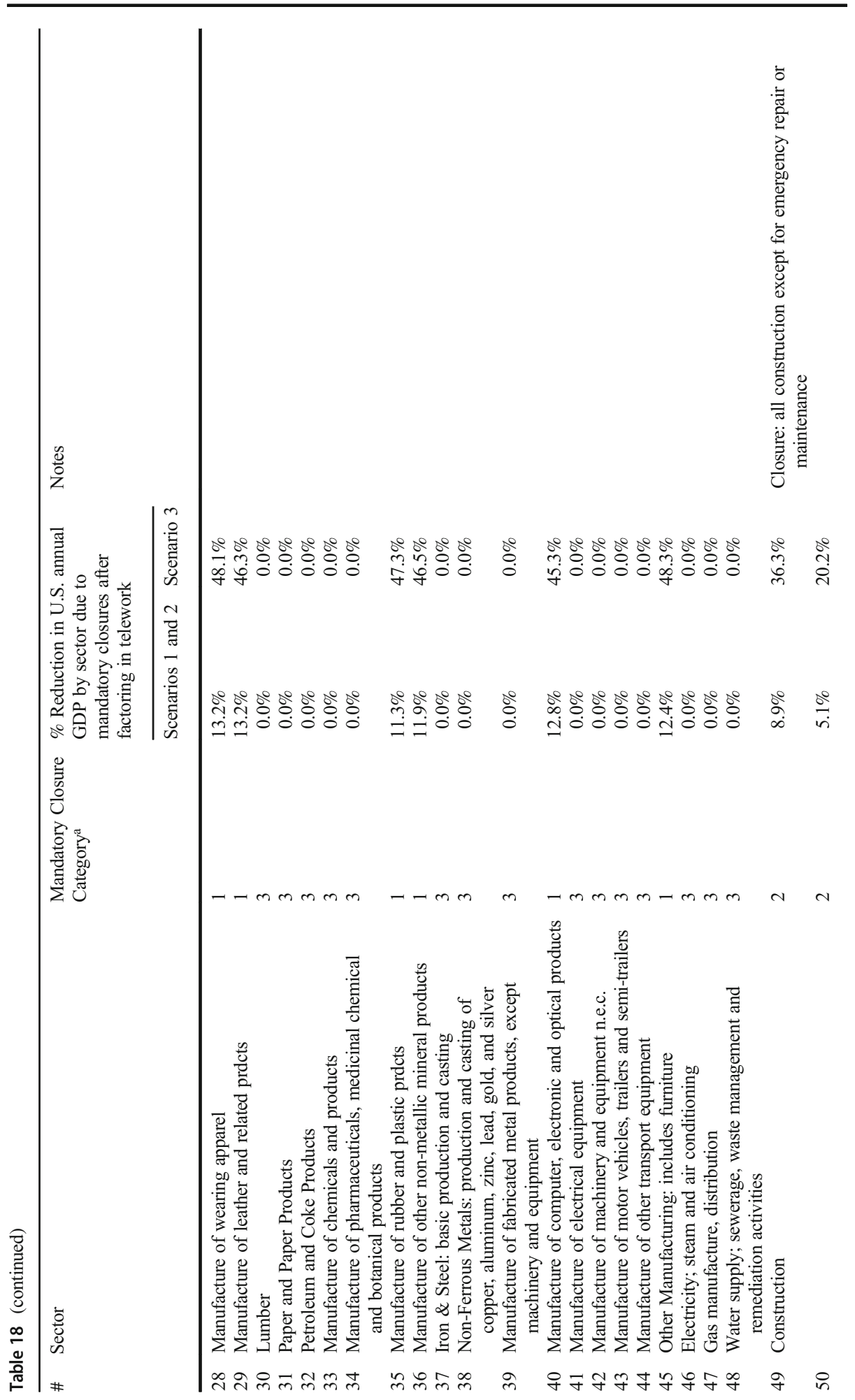




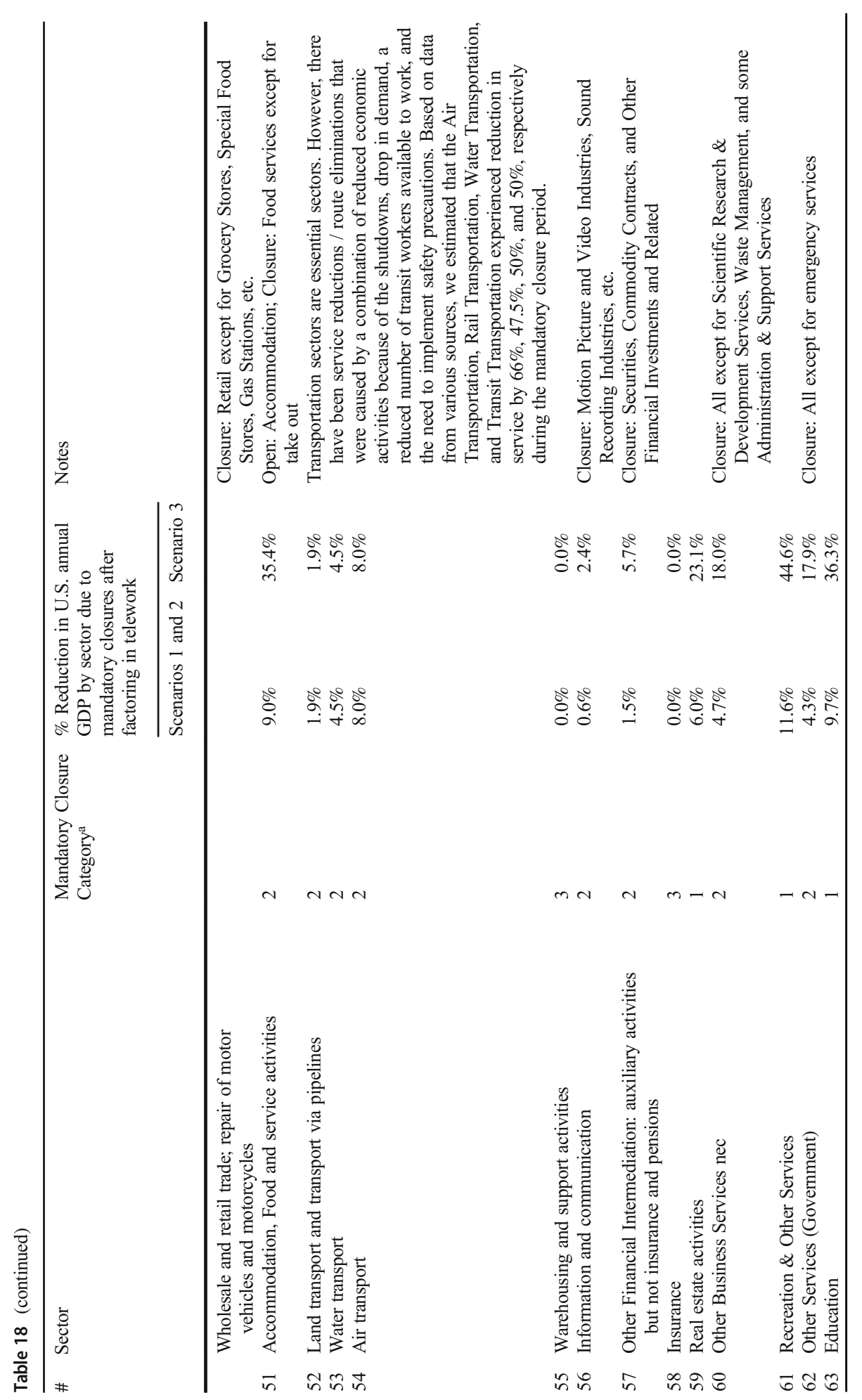




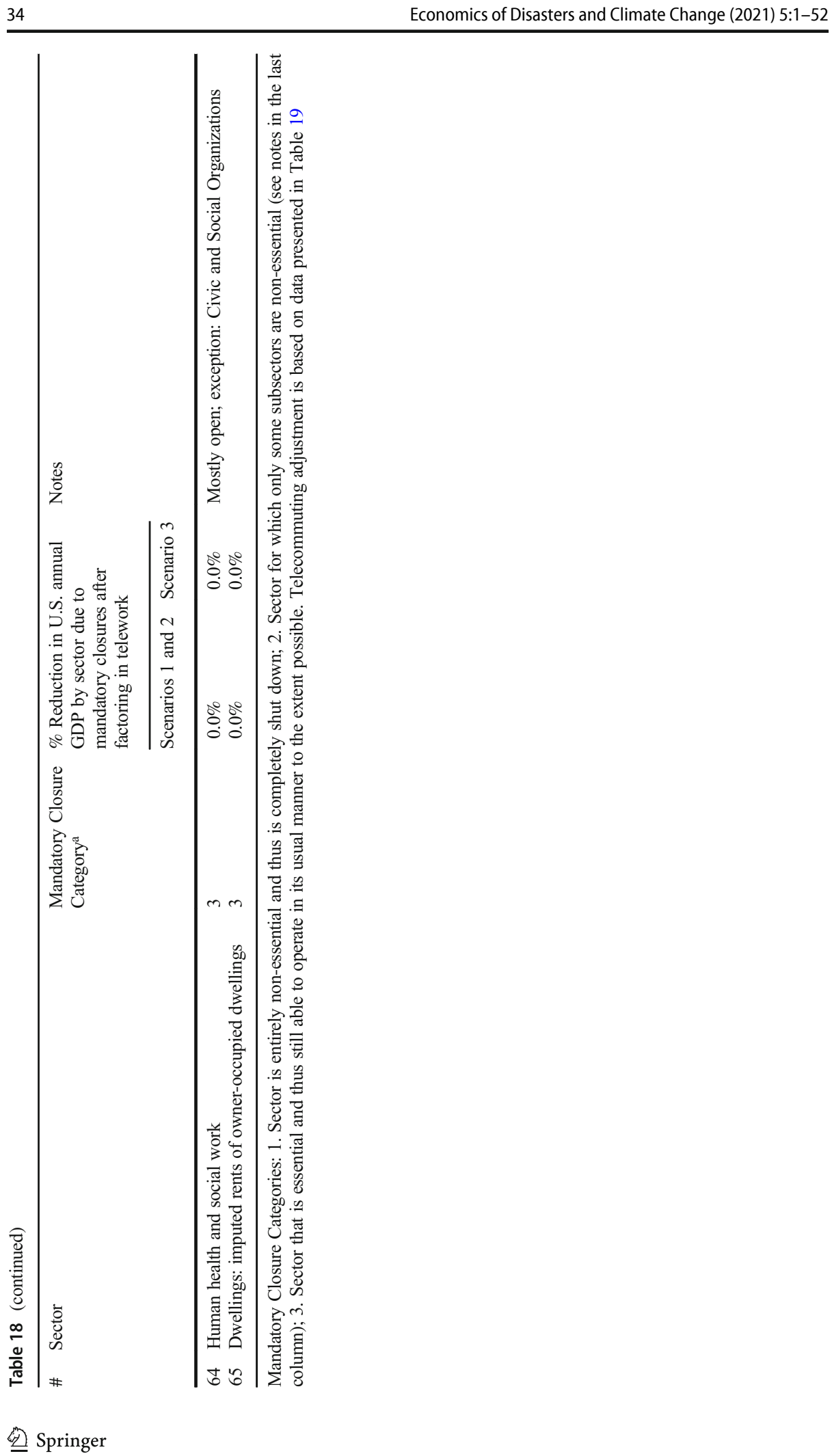




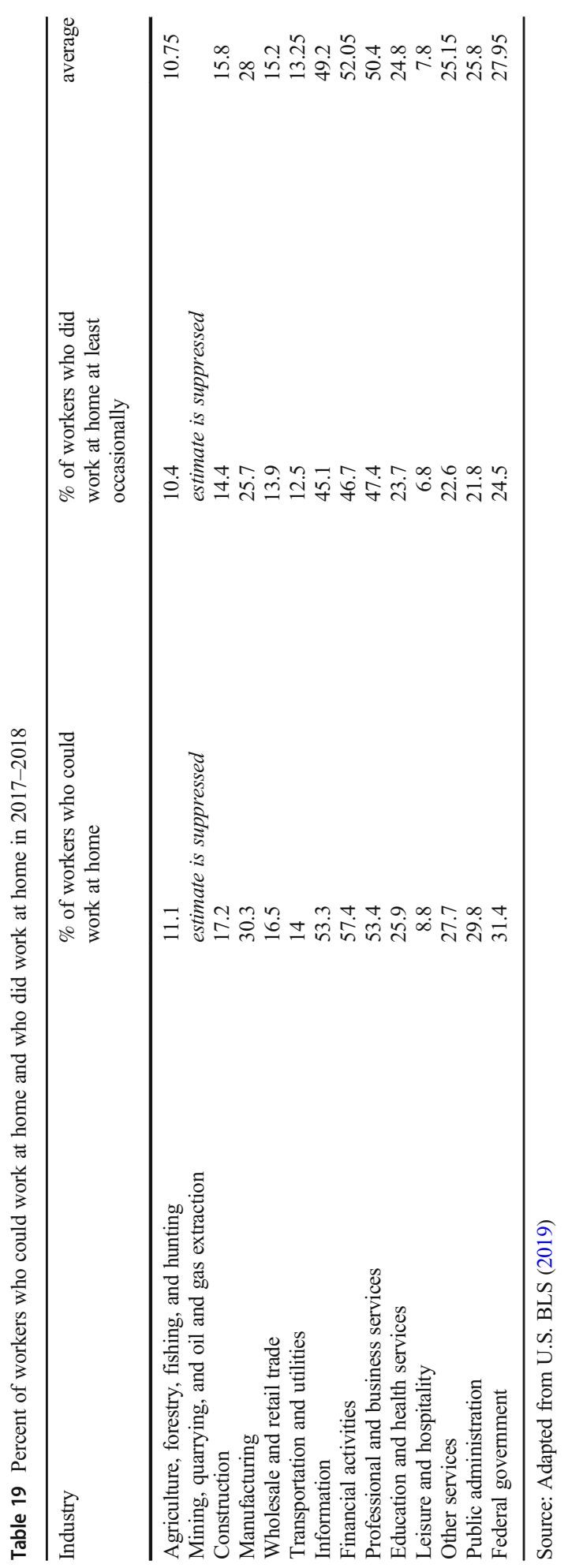


Table 20 Reopening plans in five major states

\begin{tabular}{|c|c|c|c|}
\hline State & Reopening Stages & Timeline & Regional scope \\
\hline California & $\begin{array}{l}\text { Stage 1: Government and } \\
\text { private organizations are } \\
\text { working to make it more } \\
\text { consistently safe for essential } \\
\text { workers, like grocery store } \\
\text { employees or nurses. } \\
\text { Stage } 2 \text { (May 8): Some } \\
\text { lower-risk businesses and } \\
\text { public spaces can reopen, al- } \\
\text { so with modifications to al- } \\
\text { low for distancing. Includes } \\
\text { retail (curbside and delivery } \\
\text { only), related logistics and } \\
\text { manufacturing, office } \\
\text { workplaces, limited personal } \\
\text { services, outdoor museums, } \\
\text { child care, and essential } \\
\text { businesses can open with } \\
\text { modifications. } \\
\text { Stage } 3: \text { Higher-risk businesses } \\
\text { will be able to reopen with } \\
\text { modifications. Includes nail } \\
\text { and hair salons, gyms, movie } \\
\text { theaters and sports without } \\
\text { live audiences, as well as } \\
\text { in-person religious services. } \\
\text { Stage } 4: \text { The end of the state's } \\
\text { stay-at-home order. That will } \\
\text { be when concerts, conven- } \\
\text { tions and sports with a live } \\
\text { crowd will be allowed to re- } \\
\text { open. }\end{array}$ & $\begin{array}{l}\text { California entered Stage } 2 \text { on } \\
\text { Friday, May } 8 \text {. Schools and } \\
\text { dine-in restaurants with } \\
\text { modifications, will be part of } \\
\text { a later Stage } 2 \text { statewide } \\
\text { opening. The third phase } \\
\text { may come in June over the } \\
\text { next few weeks, but these } \\
\text { businesses will not reopen all } \\
\text { at the same time. Rather, the } \\
\text { state plans to slowly roll out } \\
\text { openings and ease restric- } \\
\text { tions in the coming weeks. } \\
\text { Stage } 4 \text { will be allowed only } \\
\text { once treatments or a vaccine } \\
\text { have been developed. }\end{array}$ & $\begin{array}{l}\text { Counties that want to reopen } \\
\text { their economies faster can } \\
\text { apply for a variance from } \\
\text { state orders, provided that } \\
\text { they meet public health } \\
\text { guidelines. The governor } \\
\text { estimates that all but five of } \\
\text { California's } 58 \text { counties } \\
\text { would qualify for a variance, } \\
\text { but the list is unlikely to } \\
\text { include populous counties } \\
\text { such as LA. }\end{array}$ \\
\hline Texas & $\begin{array}{l}\text { Phase I (May 1): All retail } \\
\text { stores, restaurants, movie } \\
\text { theaters, and malls are } \\
\text { permitted to reopen. These } \\
\text { services must limit their } \\
\text { capacity to } 25 \% \text { of their } \\
\text { listed occupancy. } \\
\text { Phase II (May 18-31): } \\
\text { Restaurants may increase } \\
\text { occupancy to 50\%, } \\
\text { businesses located in office } \\
\text { buildings may also open but } \\
\text { must limit their occupancy, } \\
\text { and childcare centers may } \\
\text { open. } \\
\text { Other phases not announced }\end{array}$ & $\begin{array}{l}\text { Reopening will be staggered } \\
\text { from May } 18-31 \text { depending } \\
\text { on business activity. Unclear } \\
\text { what the other phase are and } \\
\text { when they may be } \\
\text { announced, but Texas has } \\
\text { been on aggressive reopening } \\
\text { timeline. }\end{array}$ & $\begin{array}{l}\text { Certain counties experiencing } \\
\text { surges in COVID-19 cases } \\
\text { will have their beginning } \\
\text { date of Phase II delayed until } \\
\text { May } 29 .\end{array}$ \\
\hline $\begin{array}{l}\text { New } \\
\text { York }\end{array}$ & $\begin{array}{l}\text { Phase I (Entire state except for } \\
\text { Long Island, New York City, } \\
\text { and mid-Hudson region): } \\
\text { Agriculture, Forestry, Fish- } \\
\text { ing and Hunting, Retail } \\
\text { (curbside or in-store pickup), } \\
\text { Manufacturing, Wholesale } \\
\text { Trade }\end{array}$ & $\begin{array}{l}\text { Eligibility for reopening will be } \\
\text { determined by health metrics } \\
\text { for each region. It is unclear } \\
\text { when regions may move to } \\
\text { Phase Two. }\end{array}$ & $\begin{array}{l}\text { Eligibility is determined by } \\
\text { region. }\end{array}$ \\
\hline
\end{tabular}


Table 20 (continued)

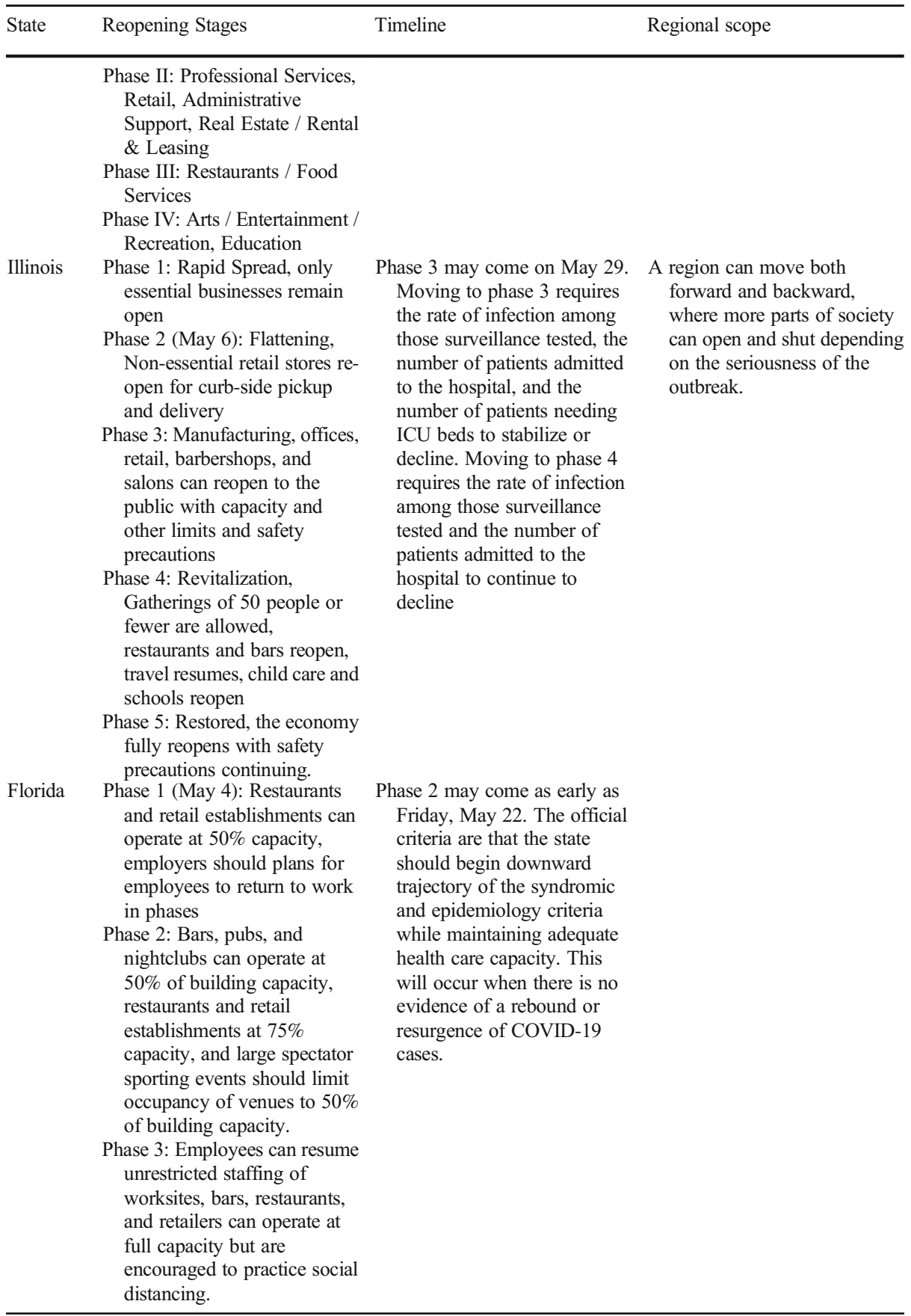


Table 21 Percentage reduction of output by sector due to phased-in reopening (with telecommuting)

\begin{tabular}{lll}
\hline \# Sector & Mandatory & \% Reduction in U.S. annual \\
& Closure & GDP by sector due to phased-in \\
& Category $^{\text {a }}$ & reopening after factoring in \\
& & telework
\end{tabular}

Scenarios 1 Scenario 2 Scenario 3

\begin{tabular}{|c|c|c|c|c|c|}
\hline 1 & Rice & 3 & $0.0 \%$ & $0.0 \%$ & $0.0 \%$ \\
\hline 2 & Wheat & 3 & $0.0 \%$ & $0.0 \%$ & $0.0 \%$ \\
\hline 3 & Other Grains & 3 & $0.0 \%$ & $0.0 \%$ & $0.0 \%$ \\
\hline 4 & Veg \& Fruit & 3 & $0.0 \%$ & $0.0 \%$ & $0.0 \%$ \\
\hline 5 & Oil Seeds & 3 & $0.0 \%$ & $0.0 \%$ & $0.0 \%$ \\
\hline 6 & Cane \& Beet & 3 & $0.0 \%$ & $0.0 \%$ & $0.0 \%$ \\
\hline 7 & Fibers crops & 3 & $0.0 \%$ & $0.0 \%$ & $0.0 \%$ \\
\hline 8 & Other Crops & 3 & $0.0 \%$ & $0.0 \%$ & $0.0 \%$ \\
\hline 9 & Cattle & 3 & $0.0 \%$ & $0.0 \%$ & $0.0 \%$ \\
\hline 10 & Other Animal Products & 3 & $0.0 \%$ & $0.0 \%$ & $0.0 \%$ \\
\hline 11 & Raw milk & 3 & $0.0 \%$ & $0.0 \%$ & $0.0 \%$ \\
\hline 12 & Wool & 3 & $0.0 \%$ & $0.0 \%$ & $0.0 \%$ \\
\hline 13 & Forestry & 3 & $0.0 \%$ & $0.0 \%$ & $0.0 \%$ \\
\hline 14 & Fishing: hunting, trapping and game propagation & 3 & $0.0 \%$ & $0.0 \%$ & $0.0 \%$ \\
\hline 15 & Coal: mining & 3 & $0.0 \%$ & $0.0 \%$ & $0.0 \%$ \\
\hline 16 & Oil: extraction of crude petroleum & 3 & $0.0 \%$ & $0.0 \%$ & $0.0 \%$ \\
\hline 17 & Gas: extraction of natural gas & 3 & $0.0 \%$ & $0.0 \%$ & $0.0 \%$ \\
\hline 18 & Other Mining Extraction & 3 & $0.0 \%$ & $0.0 \%$ & $0.0 \%$ \\
\hline 19 & Cattle Meat & 3 & $0.0 \%$ & $0.0 \%$ & $0.0 \%$ \\
\hline 20 & Other Meat & 3 & $0.0 \%$ & $0.0 \%$ & $0.0 \%$ \\
\hline 21 & Vegetable Oils & 3 & $0.0 \%$ & $0.0 \%$ & $0.0 \%$ \\
\hline 22 & Milk: dairy products & 3 & $0.0 \%$ & $0.0 \%$ & $0.0 \%$ \\
\hline 23 & Processed Rice: semi- or wholly milled, or husked & 3 & $0.0 \%$ & $0.0 \%$ & $0.0 \%$ \\
\hline 24 & Sugar and molasses & 3 & $0.0 \%$ & $0.0 \%$ & $0.0 \%$ \\
\hline 25 & Other Food & 3 & $0.0 \%$ & $0.0 \%$ & $0.0 \%$ \\
\hline 26 & Beverages and Tobacco products & 2 & $1.4 \%$ & $5.8 \%$ & $3.1 \%$ \\
\hline 27 & Manufacture of textiles & 1 & $6.1 \%$ & $24.3 \%$ & $12.5 \%$ \\
\hline 28 & Manufacture of wearing apparel & 1 & $6.0 \%$ & $24.2 \%$ & $12.5 \%$ \\
\hline 29 & Manufacture of leather and related products & 1 & $5.8 \%$ & $23.4 \%$ & $12.5 \%$ \\
\hline 30 & Lumber & 3 & $0.0 \%$ & $0.0 \%$ & $0.0 \%$ \\
\hline 31 & Paper and Paper Products & 3 & $0.0 \%$ & $0.0 \%$ & $0.0 \%$ \\
\hline 32 & Petroleum and Coke Products & 3 & $0.0 \%$ & $0.0 \%$ & $0.0 \%$ \\
\hline 33 & Manufacture of chemicals and chemical products & 3 & $0.0 \%$ & $0.0 \%$ & $0.0 \%$ \\
\hline 34 & $\begin{array}{l}\text { Manufacture of pharmaceualmsley and Mino } \\
\text { ticals, medicinal chemical and botanical products }\end{array}$ & 3 & $0.0 \%$ & $0.0 \%$ & $0.0 \%$ \\
\hline 35 & Manufacture of rubber and plastics products & 1 & $6.0 \%$ & $23.9 \%$ & $12.5 \%$ \\
\hline 36 & Manufacture of other non-metallic mineral products & 1 & $5.9 \%$ & $23.7 \%$ & $12.5 \%$ \\
\hline 37 & Iron \& Steel: basic production and casting & 3 & $0.0 \%$ & $0.0 \%$ & $0.0 \%$ \\
\hline 38 & $\begin{array}{l}\text { Non-Ferrous Metals: production and casting of } \\
\text { copper, aluminum, zinc, lead, gold, and silver }\end{array}$ & 3 & $0.0 \%$ & $0.0 \%$ & $0.0 \%$ \\
\hline 39 & $\begin{array}{l}\text { Manufacture of fabricated metal products, except } \\
\text { machinery and equipment }\end{array}$ & 3 & $0.0 \%$ & $0.0 \%$ & $0.0 \%$ \\
\hline 40 & $\begin{array}{l}\text { Manufacture of computer, electronic and optical } \\
\text { products }\end{array}$ & 1 & $5.8 \%$ & $23.0 \%$ & $12.5 \%$ \\
\hline 41 & Manufacture of electrical equipment & 3 & $0.0 \%$ & $0.0 \%$ & $0.0 \%$ \\
\hline 42 & Manufacture of machinery and equipment n.e.c. & 3 & $0.0 \%$ & $0.0 \%$ & $0.0 \%$ \\
\hline 43 & $\begin{array}{l}\text { Manufacture of motor vehicles, trailers and } \\
\text { semi-trailers }\end{array}$ & 3 & $0.0 \%$ & $0.0 \%$ & $0.0 \%$ \\
\hline 44 & Manufacture of other transport equipment & 3 & $0.0 \%$ & $0.0 \%$ & $0.0 \%$ \\
\hline 45 & Other Manufacturing: includes furniture & 1 & $6.1 \%$ & $24.3 \%$ & $12.5 \%$ \\
\hline 46 & Electricity; steam and air conditioning supply & 3 & $0.0 \%$ & $0.0 \%$ & $0.0 \%$ \\
\hline
\end{tabular}


Table 21 (continued)

\begin{tabular}{|c|c|c|c|c|c|}
\hline \multirow[t]{2}{*}{ \# } & \multirow[t]{2}{*}{ Sector } & \multirow[t]{2}{*}{$\begin{array}{l}\text { Mandatory } \\
\text { Closure } \\
\text { Category }^{\mathrm{a}}\end{array}$} & \multicolumn{3}{|c|}{$\begin{array}{l}\text { \% Reduction in U.S. annual } \\
\text { GDP by sector due to phased-in } \\
\text { reopening after factoring in } \\
\text { telework }\end{array}$} \\
\hline & & & Scenarios 1 & Scenario 2 & Scenario 3 \\
\hline 47 & Gas manufacture, distribution & 3 & $0.0 \%$ & $0.0 \%$ & $0.0 \%$ \\
\hline 48 & $\begin{array}{l}\text { Water supply; sewerage, waste management } \\
\text { and remediation activities }\end{array}$ & 3 & $0.0 \%$ & $0.0 \%$ & $0.0 \%$ \\
\hline 49 & Construction & 2 & $4.6 \%$ & $18.3 \%$ & $9.4 \%$ \\
\hline 50 & $\begin{array}{l}\text { Wholesale and retail trade; repair of motor } \\
\text { vehicles and motorcycles }\end{array}$ & 2 & $2.5 \%$ & $10.2 \%$ & $5.3 \%$ \\
\hline 51 & Accommodation, Food and service activities & 2 & $5.9 \%$ & $23.8 \%$ & $12.5 \%$ \\
\hline 52 & Land transport and transport via pipelines & 2 & $1.2 \%$ & $5.0 \%$ & $2.6 \%$ \\
\hline 53 & Water transport & 2 & $3.1 \%$ & $12.3 \%$ & $6.3 \%$ \\
\hline 54 & Air transport & 2 & $5.1 \%$ & $20.5 \%$ & $11.0 \%$ \\
\hline 55 & Warehousing and support activities & 3 & $0.0 \%$ & $0.0 \%$ & $0.0 \%$ \\
\hline 56 & Information and communication & 2 & $0.6 \%$ & $2.5 \%$ & $1.3 \%$ \\
\hline 57 & $\begin{array}{l}\text { Other Financial Intermediation: includes } \\
\text { auxiliary activities but not insurance and } \\
\text { pension funding }\end{array}$ & 2 & $1.4 \%$ & $5.8 \%$ & $3.0 \%$ \\
\hline 58 & Insurance & 3 & $0.0 \%$ & $0.0 \%$ & $0.0 \%$ \\
\hline 59 & Real estate activities & 1 & $6.8 \%$ & $27.1 \%$ & $14.0 \%$ \\
\hline 60 & Other Business Services nec & 2 & $5.3 \%$ & $21.1 \%$ & $10.9 \%$ \\
\hline 61 & Recreation \& Other Services & 1 & $18.7 \%$ & $74.8 \%$ & $38.4 \%$ \\
\hline 62 & Other Services (Government) & 2 & $2.6 \%$ & $10.5 \%$ & $5.4 \%$ \\
\hline 63 & Education & 1 & $15.3 \%$ & $61.0 \%$ & $31.3 \%$ \\
\hline 64 & Human health and social work & 3 & $0.0 \%$ & $0.0 \%$ & $0.0 \%$ \\
\hline 65 & $\begin{array}{l}\text { Dwellings: imputed rents of owner-occupied } \\
\text { dwellings }\end{array}$ & 3 & $0.0 \%$ & $0.0 \%$ & $0.0 \%$ \\
\hline
\end{tabular}

behavior by either using the most up-to-date estimate or by taking an average of up to three of the most recent surveys conducted before shutdown orders when multiple polls asked questions in comparable ways (see Appendix Table 22 for a full summary of the studies reviewed).

$29 \%$ of respondents were working from home because of the virus (ABC News/Ipsos Poll, March 20)

$11 \%$ have kept children home from school (The Associated Press, March 19; Reuters/ Ipsos, March 17)

$6 \%$ have canceled or postponed a medical appointment (USC, March 13).

$23 \%$ said they had more frequently used e-commerce to purchase products (Ipsos, March 2020).

$53 \%$ have canceled plans to attend events with large crowds (ABC News/Ipsos Poll, March 20; Gallup, March 20; NPR/PBS NewsHour/Marist Poll, March 17)

$55.5 \%$ have canceled or avoided going to restaurants (ABC News/Ipsos Poll, March 20; Gallup, March 20)

37.5\% have canceled or postponed travel plans (Gallup, March 20; NPR/PBS NewsHour/ Marist Poll, March 17; Reuters/Ipsos, March 17) 
Table 22 Summary of U.S. public opinion polls on avoidance behaviors before COVID-19 shutdowns

\begin{tabular}{|c|c|c|}
\hline Avoidance Responses & Percent Who Avoid & Data Source \\
\hline $\begin{array}{l}\text { Staying Home } \\
\text { from Work }\end{array}$ & $\begin{array}{l}\text { Working from home: } \\
\text { - } 29 \% \text { of those employed were working from } \\
\text { home because of the virus (3/18-3/19) } \\
\text { - } 16 \% \text { of those employed said they are } \\
\text { working } \\
\text { from home every day and an } \\
\text { additional } 10 \% \\
\text { said they are working some days from } \\
\text { home } \\
\text { because of the virus }(3 / 18-3 / 19) \\
\text { - } 16 \% \text { said they have worked from home } \\
\text { at } \\
\text { least once because of the virus } \\
(3 / 16-3 / 17) \\
\text { - } 21 \% \text { of those employed had been told to } \\
\text { work remotely or from home } \\
(3 / 13-3 / 16) \\
\text { - } 26 \% \text { stayed home instead of going to } \\
\text { work } \\
\text { or other regular activities }(3 / 11-3 / 15)\end{array}$ & $\begin{array}{l}\text { Axios/Ipsos Poll (2020a) (Mar 17) } \\
\text { Kaiser Family Foundation (2020a) } \\
\quad \text { (Mar 17) }\end{array}$ \\
\hline $\begin{array}{l}\text { Keeping Children } \\
\text { from School }\end{array}$ & $\begin{array}{l}\text { Kept children home from school: } \\
\text { - } 11 \%(3 / 16-3 / 17) \\
\text { 11\% (3/12-3/16) } \\
38 \% \text { said their child's daycare, K-12 } \\
\text { school, } \\
\text { or college has closed or stopped } \\
\text { in-person } \\
\text { classes }(3 / 11-3 / 13)\end{array}$ & $\begin{array}{l}\text { Reuters/Ipsos (2020) (Mar 17) } \\
\text { The Associated Press (2020) (Mar 19) } \\
\text { NBC News/Wall Street } \\
\text { Journal (2020) (March) }\end{array}$ \\
\hline $\begin{array}{l}\text { Avoiding Medical } \\
\text { Professionals }\end{array}$ & $\begin{array}{l}6 \% \text { have canceled or postponed a } \\
\text { medical } \\
\text { appointment }(3 / 10-3 / 12)\end{array}$ & USC (2020) (Mar 13) \\
\hline Reducing Shopping & $\begin{array}{l}11 \% \text { attempted to visit a store or business } \\
\text { that is closed due to the virus } \\
(3 / 13-3 / 16) \\
23 \% \text { said they had more frequently used } \\
\text { e-commerce to purchase products they } \\
\text { would normally buy in-store } \\
(3 / 12-3 / 14)\end{array}$ & Axios/Ipsos Poll (2020a) (Mar 17) \\
\hline $\begin{array}{l}\text { Avoiding Local } \\
\text { Leisure Activities }\end{array}$ & $\begin{array}{l}\text { Events with large crowds: } \\
\text { - } 32 \% \text { have canceled or postponed plans } \\
\text { to } \\
\text { attend a sporting event or concert } \\
(3 / 18-3 / 19) \\
\text { - } 79 \% \text { avoided going to events with large } \\
\text { crowds }(3 / 16-3 / 19) \\
\text { - } 48 \% \text { canceled plans to avoid crowds } \\
\text { (3/13-3/14) } \\
\text { - } 68 \% \text { said there were staying away from } \\
\text { large groups }(3 / 12-3 / 16) \\
\text { Dining out: } \\
\text { - } 57 \% \text { canceled or postponed plans to go } \\
\text { to dinner }(3 / 18-3 / 19) \\
\text { - } 54 \% \text { avoided going to public places, } \\
\text { such as stores or restaurants } \\
\text { (3/16-3/19) } \\
\text { - } 46 \% \text { decided to eat at home more } \\
\text { often? }(3 / 13-3 / 14) \\
\text { - } 13 \% \text { stopped eating out at restaurants } \\
(3 / 11-3 / 13) \\
\text { - } 25 \% \text { avoided restaurants }(3 / 10-3 / 12)\end{array}$ & $\begin{array}{l}\text { ABC News/Ipsos Poll (2020b) (Mar 20) } \\
\text { Gallup (2020) (Mar 20) } \\
\text { NPR/PBS NewsHour/Marist } \\
\text { Poll (2020) (Mar 17) } \\
\text { NBC News/Wall Street } \\
\text { Journal (2020) (March) } \\
\text { USC (2020) (Mar 13) }\end{array}$ \\
\hline $\begin{array}{l}\text { Avoiding Public } \\
\text { Transportation } \\
\text { Canceling Travel Plans }\end{array}$ & $\begin{array}{l}24 \% \text { are avoiding public transportation } \\
(3 / 16-3 / 17) \\
\text { Canceled/changed/postponed travel } \\
\text { plans: } \\
\text { - } 57 \%(3 / 16-3 / 19)\end{array}$ & Reuters/Ipsos (2020) (Mar 17) \\
\hline
\end{tabular}


Table 22 (continued)

\begin{tabular}{|c|c|c|}
\hline Avoidance Responses & Percent Who Avoid & Data Source \\
\hline $\begin{array}{l}\text { General Avoidance } \\
\text { Behavior }\end{array}$ & $\begin{array}{l}\text { - } 25 \%(3 / 16-3 / 17) \\
\text { - } 30 \%(3 / 13-3 / 14) \\
\text { - } 42 \%(3 / 11-3 / 15) \\
\text { - } 19 \%(3 / 11-3 / 13) \\
\text { Canceled/changed/postponed business } \\
\text { trips: } \\
\text { - } 13 \%(3 / 18-3 / 19) \\
\text { - } 20 \% \text { of those employed (3/18-3/19) } \\
\text { International/Domestic: } \\
\text { - 5\% have canceled international trips } \\
\text { over the next three months } \\
\text { (3/12-3/16) } \\
\text { - } 9 \% \text { have canceled domestic trips over } \\
\text { the next three months }(3 / 12-3 / 16) \\
75 \% \text { avoided traveling by airplane, bus, } \\
\text { subway or train }(3 / 16-3 / 19) \\
\text { Large gatherings: } \\
\text { - 56\% avoiding large gatherings of } \\
\text { people whenever possible }(3 / 16-3 / 17) \\
\text { - 46\% canceled or skipped attending } \\
\text { large gatherings over the last week } \\
\text { (3/13-3/16) } \\
\text { - } 40 \% \text { canceled plans to attend large } \\
\text { gatherings }(3 / 11-3 / 15) \\
\text { - 25\% stopped attending large } \\
\text { public gatherings }(3 / 11-3 / 13)\end{array}$ & $\begin{array}{l}\text { ABC News/Ipsos Poll (2020b) (Mar 20) } \\
\text { SurveyUSA (2020) (Mar 19) } \\
\text { The Associated Press (2020) (Mar 19) } \\
\text { The Associated Press (2020) (Mar 19) } \\
\text { Gallup (2020) (Mar 20) }\end{array}$ \\
\hline
\end{tabular}

47.5\% are avoiding large gatherings of people (Axios/Ipsos Poll, March 17; Kaiser, March 17; Reuters/Ipsos, March 17)

The proportion of respondents indicating they are practicing a type of avoidance behavior has generally increased over time, as the number of cases in the United States has grown.

\section{Avoidance Behavior After Restriction Orders Are Lifted}

We reviewed the results of 9 most recent public opinion polls that asked people's willingness to resume activities after their state lifts shutdown orders. People's indications on when they believe it would be safe to resume certain activities are also reviewed. The results are summarized in Appendix Table 23.

In our scenario analysis, three levels (low, moderate, high) of avoidance behavior are simulated with respect to the magnitude and length of such behaviors. Appendix Table 24 summarize the parameters we estimated based on the various public opinion polls reviewed above. We adopted the following methods to translate the survey results in each study to low, moderate, and high estimates.

ABC News/Ipsos Poll (May 1): Use the \% of "not likely at all" as the low estimate; use sum of "not likely at all" and "not so likely" as the high estimate; use the average of the low and high estimates as the moderate estimate.

Morin (May 8): Use the \% of respondents that indicate the most conservative and prudent behavior in terms of the length of avoidance they will take as the low estimate; add the next 
Table 23 Summary of U.S. Public opinion polls on avoidance behaviors after COVID-19 restrictions are lifted

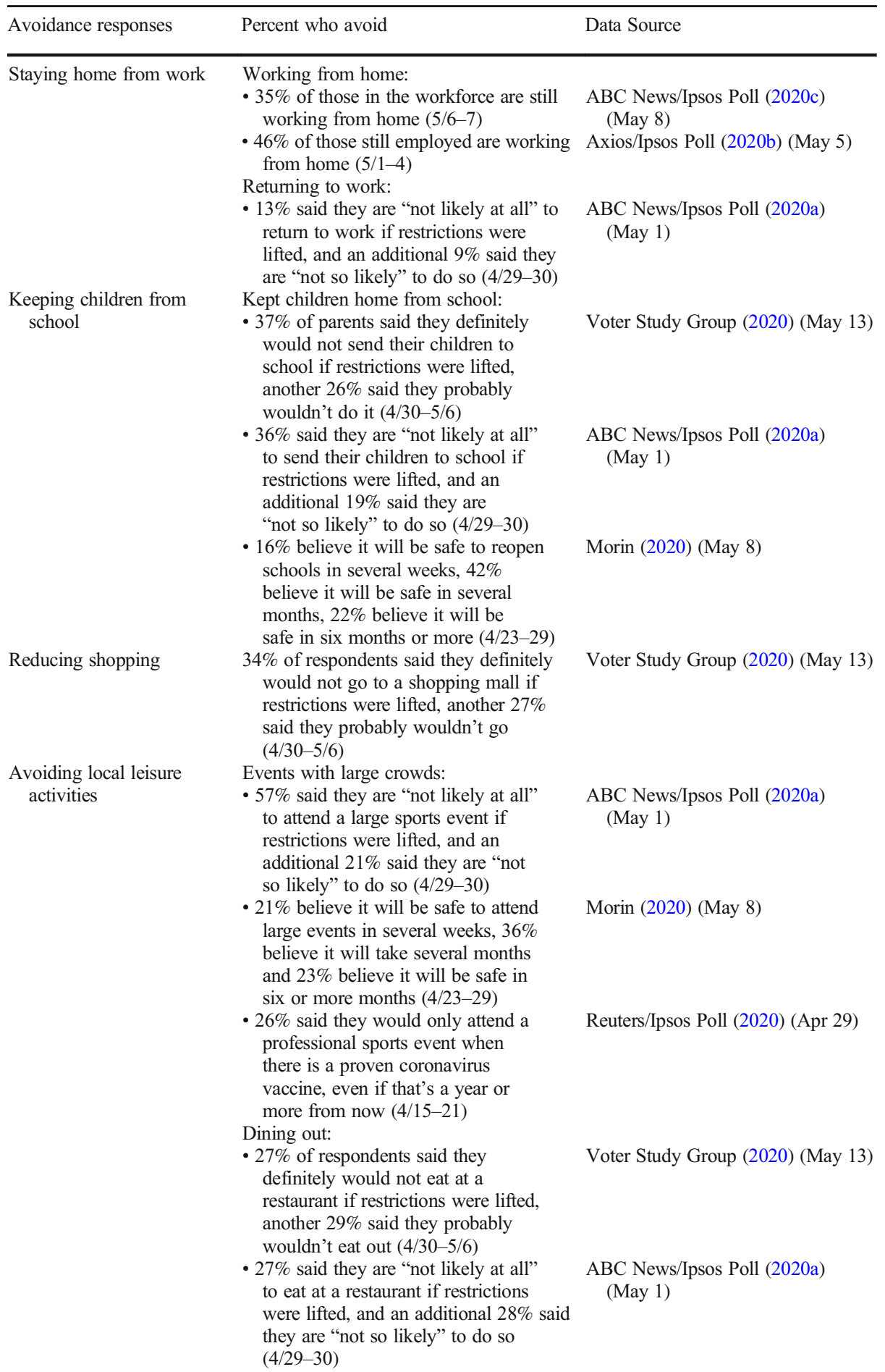


Table 23 (continued)

\begin{tabular}{|c|c|c|}
\hline Avoidance responses & Percent who avoid & Data Source \\
\hline & $\begin{array}{l}26 \% \text { believe it will be safe for theaters, } \\
\text { restaurants, and bars to open in several } \\
\text { weeks, } 35 \% \text { believe it will be safe in } \\
\text { several months, and } 17 \% \text { believe it } \\
\text { will be safe in six or more months } \\
(4 / 23-29)\end{array}$ & Morin (2020) (May 8) \\
\hline \multirow[t]{2}{*}{$\begin{array}{r}\text { Avoiding public } \\
\text { transportation }\end{array}$} & $\begin{array}{l}\text { - } 44 \% \text { of respondents said they definitely } \\
\text { would not take public transit if } \\
\text { restrictions were lifted, another } 28 \% \\
\text { said } \\
\text { they probably wouldn't do it }(4 / 30-5 / 6)\end{array}$ & Voter Study Group (2020) (May 13) \\
\hline & $\begin{array}{l}67 \% \text { said traveling on airplane or mass } \\
\text { transit was a large risk, and another } \\
23 \% \text { said it was a moderate risk }(5 / 1-4)\end{array}$ & Axios/Ipsos Poll (2020b) (May 5) \\
\hline \multirow[t]{3}{*}{ Canceling travel plans } & Airplane trips: & \\
\hline & $\begin{array}{l}\text { - } 41 \% \text { of respondents said they definitely } \\
\text { would not fly if restrictions were lifted, } \\
\text { another } 27 \% \text { said they probably } \\
\text { wouldn't do it }(4 / 30-5 / 6)\end{array}$ & Voter Study Group (2020) (May 13) \\
\hline & $\begin{array}{l}\text { - } 44 \% \text { said they are "not likely at all" to } \\
\text { fly if restrictions were lifted, and an } \\
\text { additional } 25 \% \text { said they are "not so } \\
\text { likely" to do so }(4 / 29-30)\end{array}$ & $\begin{array}{l}\text { ABC News/Ipsos Poll (2020a) } \\
\text { (May 1) }\end{array}$ \\
\hline \multirow[t]{5}{*}{ General avoidance behavior } & $\begin{array}{l}\text { - } 35 \% \text { say it won't be safe to lift } \\
\text { stay-at-home orders for several weeks, } \\
30 \% \text { say it would take several months, } \\
\text { and } 12 \% \text { say six or more months } \\
(4 / 23-29)\end{array}$ & Morin (2020) (May 8) \\
\hline & $\begin{array}{l}\text { - Thirty-five percent believe it won't be } \\
\text { safe to lift those orders for several } \\
\text { weeks, } 30 \% \text { believe it won't be safe } \\
\text { for several months, and } 12 \% \text { believe } \\
\text { it won't be safe to lift until six or } \\
\text { more months. }\end{array}$ & Morin (2020) (May 8) \\
\hline & $\begin{array}{l}29 \% \text { say that it will be safe to end } \\
\text { social distancing measures and reopen } \\
\text { businesses as normal in several } \\
\text { months, } 15 \% \text { say it would take a } \\
\text { year or longer }(5 / 3-5)\end{array}$ & $\begin{array}{l}\text { The Economist/YouGov (2020) } \\
\text { (May) }\end{array}$ \\
\hline & $\begin{array}{l}\text { - } 41 \% \text { of respondents said they would } \\
\text { not go back to their normal routine } \\
\text { even if their state relaxed } \\
\text { stay-at-home orders }(4 / 23-28)\end{array}$ & Marketplace-Edison (2020) (May 5) \\
\hline & $\begin{array}{l}\text { - } 51 \% \text { say they could only follow social } \\
\text { distancing or shelter at home orders for } \\
\text { another three months or less, } 43 \% \text { say } \\
\text { they could do it for four months or } \\
\text { longer }(4 / 15-20)\end{array}$ & $\begin{array}{l}\text { Kaiser Family Foundation (2020b) } \\
\text { (April) }\end{array}$ \\
\hline
\end{tabular}

group of respondents with shorter stated avoidance duration as the moderate estimate; the high estimate is the sum of all respondents that indicated some length of intended avoidance.

Voter Study Group (May 13): Low: definitely wouldn't do activity if restrictions lifted; High: definitely wouldn't + probably wouldn't. Excludes people who said "I would not have done this before coronavirus" from the denominator. Moderate: average of Low and High. 


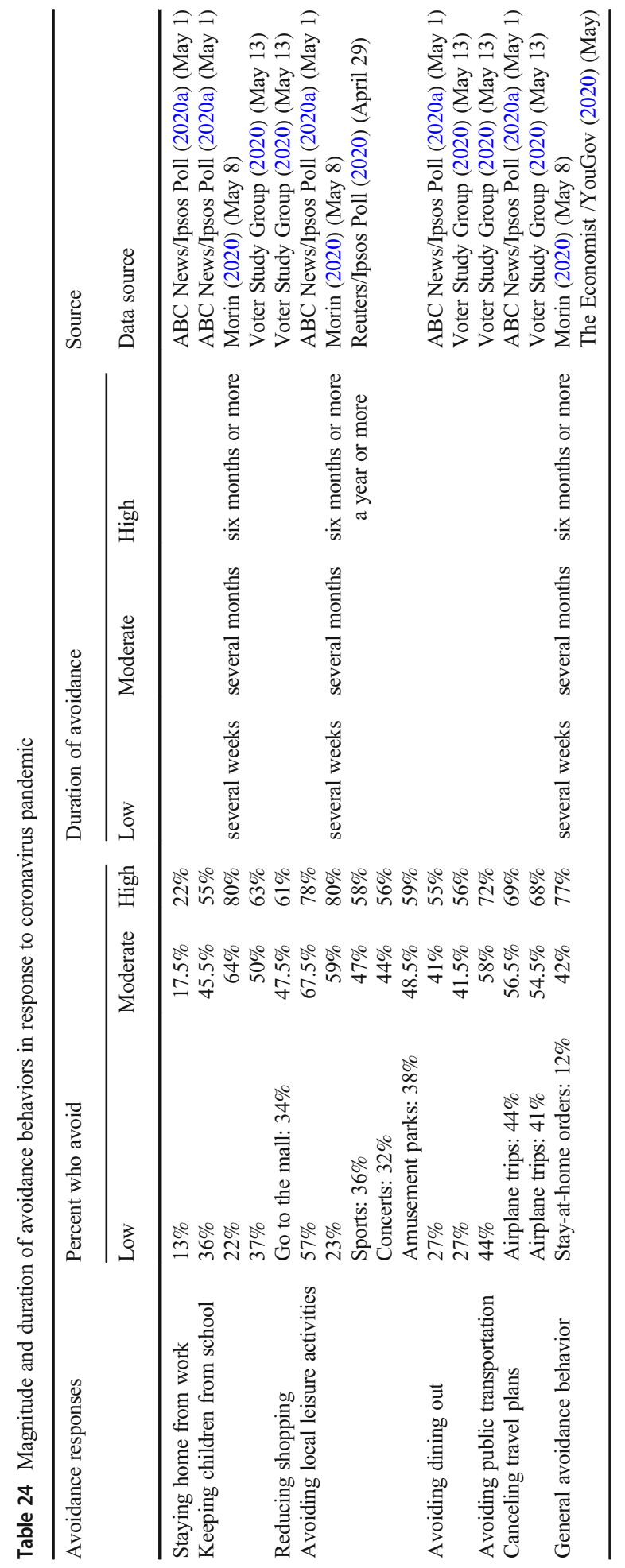


Reuters/Ipsos Poll (April 29): Use the response to survey questions such as "Please indicate how much you agree or disagree with the following statements: Professional sports (NFL, MLB, NBA, etc.) should hold competitions again with live audiences before a vaccine is available". Use \% that responded "Strongly Disagree" as the low estimate; use "Strongly Disagree" + "Somewhat Disagree" as the high estimate; use the average of low and high as moderate.

\section{Appendix 5}

\section{Estimated Impact on Revenue of Communication Sectors}

\section{NAICS 517311 Wired Telecommunications Carriers}

Estimate of instantaneous impact on revenue: $0 \%-0.5 \%$ change due to COVID- 19 .

Broadband internet providers like Charter and Comcast saw year-over-year increases of approximately $9.5 \%$ in internet revenues in the first quarter of 2020, but Comcast had experienced similarly high growth the previous quarter, and Charter had actually seen an $11.5 \%$ growth in revenue. Therefore, the increase in revenue cannot be attributed to COVID19. OpenVault, a data analytics and broadband solutions company, notes that some users have upgraded to higher speed plans since the lockdowns, but that increase is unlikely to amount to a large revenue increase.

\section{NAICS 517312 Wireless Telecommunications Carriers (except Satellite)}

Estimate of instantaneous impact on revenue: $-0.25 \%-0.25 \%$ change due to COVID- 19 .

Carriers like AT\&T and Verizon saw year-over-year increases in service revenue of 2 to $2.5 \%$ in the first quarter, but those increases were offset by lower equipment sales. Wireless revenues were flat year-over-year. AT\&T noted that across all its divisions, COVID-19 led to approximately $\$ 600$ million in losses (1.4\% of quarterly revenues), mostly from lower advertising and wireless equipment sales.

\section{NAICS 518 Data Processing, Hosting, and Related Services}

Estimate of instantaneous impact on revenue: $0 \%-2 \%$ increase.

The cloud service divisions of Amazon, Google, and Microsoft experienced rapid yearover-year growth in the first quarter of 2020, but that growth was similar or slightly lower than what they had reported the previous quarter. In the earnings call, executives from Google suggested that growth has kept pace, even during March as lockdown orders were implemented. Synergy Research Group predicts that COVID-19 is having a "mildly positive impact" on the cloud services market.

\section{NAICS 51913 Internet Publishing and Broadcasting and Web Search Portals}

Estimate of instantaneous impact on revenue: $-30 \%$ to $-10 \%$.

Companies such as Google and Facebook experienced significantly lower year-over-year revenue growth compared to previous quarters. Executives in both companies said they saw 
abrupt declines in advertisement revenue in March. Those declines resulted in year-over-year revenue growth of $17.6 \%$ for Facebook (relative to $25 \%$ last quarter), and $8.7 \%$ for Google (relative to $16.6 \%$ ). Assuming revenue growth would have followed a trajectory similar to the previous quarter absent COVID-19 and that the abrupt drop started around March 7, the immediate impact of COVID-19 was a 27\% drop in Google Search advertisement and a 24\% drop in Facebook advertisement. Netflix, which was expected to benefit from the closure of cinemas and the lack of entertainment options, also saw year-over-year revenue growth in the U.S. and Canada (19.8\%) lower than in the previous quarter (23.6\%). The slowdown would imply that COVID-19 had an instantaneous impact of $12 \%$ on its revenues.

\section{Appendix 6}

\section{Data on Pent-Up Demand}

Appendix Table 25 presents the estimates of pent-up consumer demand resulting from the COVID-19 related lockdowns across a range of key sectors, goods, and services in the U.S. The estimates provided were calculated using micro-level data from three distinct online sources: Opportunity Insights, Unacast, and SafeGraph.

Based at Harvard University, Opportunity Insights is a consortium of researchers, policy analysts, and outside collaborators working together to analyze new data and create a platform for local stakeholders to make more informed decisions. The consumption data gathered from this source was aggregated via Opportunity Insight's COVID-19 economic tracker and corresponding research paper. The economic tracker is a publicly available platform that tracks economic activity at a granular level in real-time using anonymized data from private companies to construct indices of spending, employment, and other metrics. Consumer spending is measured using purchase data collected by Affinity Solutions Inc., a company that aggregates consumer card-spending information. The pent-up demand estimates using this data were calculated by measuring the percentage-point increase in card-spending on a particular good/service from either the lowest point in the time-series or the point corresponding to May 1 up until June 18, as a percentage of the total decline in card-spending at the Lowest or May 1 point. For example, the largest dip in restaurant dining as measured by card spending occurred around the end of March and was a decline of 60\% from January 2020 levels, and as of June 18, the decline was around 35\% from January 2020 levels. This represents a 25 percentage-point increase from that farthest decline, or indicates an approximately $42 \%$ gain as a percentage of that $60 \%$ decline. The way this can be interpreted is that $42 \%$ of the decline in restaurant spending precipitated by the lockdown restrictions came back in the form of pent-up demand.

Unacast collects human mobility information from GPS and other map data sources to support business intelligence. Consumption data for the table is provided by Unacast's COVID-19 Retail Impact Scoreboard, which compares current foot traffic levels at retail locations across a variety of industries to foot traffic levels at the beginning of February 2020 (pre-COVID). The pent-up demand estimates using this data were calculated by measuring the percentage-point increase in foot traffic at retail locations in a particular industry/ service group from either the lowest point in the time-series or the point corresponding to May 1 up until June 12, as a percentage of the total decline in foot traffic at the lowest or May 1 point. For example, the largest dip in automobile purchases as measured by foot traffic 
Table 25 Pent-up demand in the U.S. by major consumption category

\begin{tabular}{|c|c|c|c|c|}
\hline Good/Service & $\begin{array}{l}\text { Opportunity } \\
\text { Insights } \\
\text { (Private card } \\
\text { spending, 6/18) }\end{array}$ & $\begin{array}{l}\text { Unacast (Foot } \\
\text { traffic, } 6 / 12 \text { ) }\end{array}$ & $\begin{array}{l}\text { SafeGraph (Foot } \\
\text { traffic, } 6 / 14)\end{array}$ & Notes \\
\hline Automobiles & N/A & $\begin{array}{l}\text { Lowest Point: } \\
\text { 79\% } \\
\text { May 1: } 71 \%\end{array}$ & N/A & $\begin{array}{l}\text { Unacast estimates include } \\
\text { Auto dealerships \& car } \\
\text { rentals }\end{array}$ \\
\hline Real Estate & N/A & N/A & N/A & \\
\hline Air Travel & N/A & $\begin{array}{l}\text { Lowest Point: } \\
\text { 47\% } \\
\text { May 1: } 38 \%\end{array}$ & $\begin{array}{l}\text { Lowest point: } \\
\text { 17\% } \\
\text { May 1: } 14 \%\end{array}$ & $\begin{array}{c}\text { Unacast estimates include } \\
\text { Travel \& Hospitality }\end{array}$ \\
\hline Restaurant Dining & $\begin{array}{l}\text { Lowest Point: } \\
\qquad 42 \% \\
\text { May 1: } 32 \%\end{array}$ & $\begin{array}{l}\text { Lowest Point: } \\
\text { 63\% } \\
\text { May 1: } 40 \%\end{array}$ & $\begin{array}{l}\text { Lowest Point: } \\
\quad 63 \% \\
\text { May 1: } 38 \%\end{array}$ & $\begin{array}{l}\text { Opportunity Insights } \\
\text { estimates include } \\
\text { Restaurant \& Hotel }\end{array}$ \\
\hline $\begin{array}{l}\text { Live Experience } \\
\text { Events }\end{array}$ & $\begin{array}{l}\text { Lowest Point: } \\
\text { 27\% } \\
\text { May 1: } 24 \%\end{array}$ & $\begin{array}{l}\text { Lowest Point: } \\
\text { 50\% } \\
\text { May 1: } 41 \%\end{array}$ & N/A & $\begin{array}{l}\text { Opportunity Insights } \\
\text { estimates include Arts, } \\
\text { entertainment, and } \\
\text { recreation; Unacast includes } \\
\text { Entertainment \& Hobby }\end{array}$ \\
\hline Apparel & $\begin{array}{l}\text { Lowest Point: } \\
\quad 75 \% \\
\text { May 1: } 59 \%\end{array}$ & $\begin{array}{l}\text { Lowest Point: } \\
\text { 44\% } \\
\text { May 1: } 40 \%\end{array}$ & N/A & $\begin{array}{l}\text { Opportunity Insights estimates } \\
\text { include Apparel \& General } \\
\text { Merchandise }\end{array}$ \\
\hline $\begin{array}{l}\text { General } \\
\text { Merchandise }\end{array}$ & $\begin{array}{l}\text { Lowest Point: } \\
75 \% \\
\text { May 1: } 59 \%\end{array}$ & $\begin{array}{l}\text { Lowest Point: } \\
52 \% \\
\text { May 1: } 22 \%\end{array}$ & $\begin{array}{l}\text { Lowest Point: } \\
\text { 96\% } \\
\text { May 1: } 88 \%\end{array}$ & $\begin{array}{l}\text { Opportunity Insights estimates } \\
\text { include Apparel \& General } \\
\text { Merchandise; Unacast: } \\
\text { General Retail }\end{array}$ \\
\hline $\begin{array}{l}\text { Hotels and other } \\
\text { Hospitality }\end{array}$ & $\begin{array}{l}\text { Lowest Point: } \\
\qquad 42 \% \\
\text { May 1: } 32 \%\end{array}$ & $\begin{array}{l}\text { Lowest Point: } \\
\text { 47\% } \\
\text { May 1: } 38 \%\end{array}$ & $\begin{array}{l}\text { Lowest Point: } \\
73 \% \\
\text { May 1: } 68 \%\end{array}$ & $\begin{array}{l}\text { Opportunity Insights estimates } \\
\text { include Restaurant \& Hotel; } \\
\text { Unacast: Travel \& Hospitality }\end{array}$ \\
\hline $\begin{array}{l}\text { Wellness and } \\
\text { Fitness }\end{array}$ & N/A & $\begin{array}{l}\text { Lowest Point: } \\
\text { 54\% } \\
\text { May 1: } 33 \%\end{array}$ & N/A & \\
\hline
\end{tabular}

at auto dealers occurred around mid-April and was a decline of about $70 \%$ compared to February 2020 levels, and as of June 12, the decline was around 15\% from February 2020 levels. This represents a 55 percentage-point increase from the farthest decline, or indicates an approximately $79 \%$ gain as a percentage of that $70 \%$ decline. The way this can be interpreted is that $79 \%$ of the decline in automobile spending precipitated by the lockdown restrictions came back in the form of pent-up demand.

SafeGraph's points-of-interest and foot traffic data are used by businesses for a variety of use cases. The consumption data used for the pent-up demand table is sourced from COVID-specific foot traffic data intended to give insight into how the US is opening up following the end of lockdowns. The dashboard is built from SafeGraph Places Patterns data, an aggregated, anonymized summary of foot traffic to 6 million points-of-interest in North America with data on over 5500 retail chains and 3-million mom-and-pop businesses. The pent-up demand estimates using this data were calculated similarly to the estimates using the Unacast data, by measuring percentage-point increases in foot traffic at retail locations across a range of industries/services/ goods from either the lowest point in the series or the May 1 point up until June 14, as a percentage of the total decline in foot traffic at the lowest or May 1 point. The baseline used is January 
2020 foot-traffic levels. As an example, the largest drop in air travel as measured by foot traffic at airports occurred around mid-April and was an $87 \%$ drop compared to January 2020 levels, and as of June 14, the decline was around $72 \%$ from January 2020 levels. This represents a 15 percentage-point increase from the farthest decline, or indicates an approximately $17 \%$ gain as a percentage of that $87 \%$ decline. The way this can be interpreted is that $17 \%$ of the decline in air travel precipitated by the lockdown restrictions came back in the form of pent-up demand.

\section{Appendix 7}

In this Appendix, we illustrate the difference between our static formulation and a dynamic one. We repeat our scenarios, though with more detail about the timephasing. In the comparative static model, these timings cannot be captured, so we take the total changes due to the mandatory closures, avoidance etc., over our time horizon, approximately a year after the beginning of the pandemic. For instance, in the case of the mandatory closures we reduce production of the industry by the effective amount of time and the share of businesses that are impacted by the closures. We depict the various processes that work in Appendix Fig. 1

Shortly after the pandemic begins, non-essential businesses are closed and real GDP starts to decline. We track actual shutdowns up to May 25, 2020, so all three scenarios initially show the same rate of decline. After May 25, as economies begin to open-up, our three scenarios diverge.

In Scenario, 1, the mandatory closures have been successful at reducing the number of COVID-19 cases. As cases continue to decline the economy is free to open-up, workers laid off due to the closures are now able to return to work and real GDP rises back towards the baseline. Growth is then likely to reverts to baseline growth, although the level of GDP is likely to be lower.

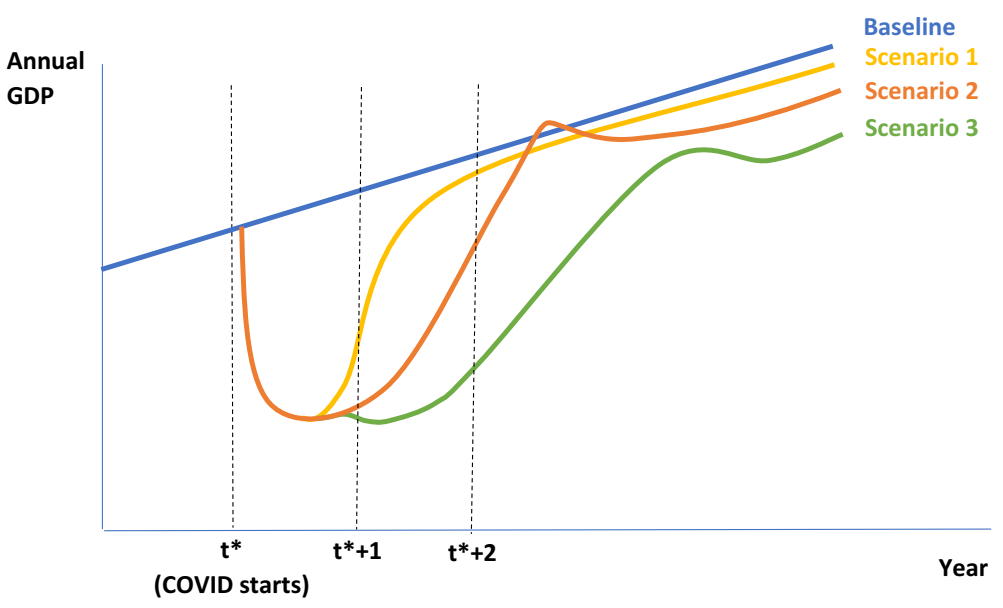

Fig. 1 Expected time-path of impacts on GDP for COVID-19 scenarios 
In Scenario, 2, as the economy begins to open up after the first round of mandatory closures, cases of COVID-19 begin to rise and the re-opening process is slowed down considerably. The rate at which GDP increases slows considerably. Assumptions regarding the possibility of pent-up demand mean that real GDP may temporarily rise above Scenario 1a or even baseline, before settling at a lower level.

In Scenario 3, cases of COVID again rise and the economy is put in lockdown again, causing GDP to fall once again (double dip). Re-opening is gradual, as in Scenario 2 and again there is extensive pent up demand, which causes GDP to rise temporarily and then fall back to a lower equilibrium level.

\section{References}

Aguiar A, Chepeliev M, Corong E, McDougall R, van der Mensbrugghe D (2019) The GTAP Data Base: Version 10. J Global Econ Anal 4(1):1-27. Retrieved from https://www.jgea.org/resources/jgea/ojs/index. php/jgea/article/view/77

Bhatraju PK, Ghassemieh BJ, Nichols M, Kim R, Jerome KR, Nalla AK, Greninger AL, Pipavath S, Wurfel MM, Evans L, Kritek PA, West TE, Luks A, Gerbino A, Dale CR, Goldman JD, O'Mahony S, Mikacenic C (2020) Covid-19 in critically ill patients in the seattle region - case series. N Engl J Med 382(21)

Comscore (2020) Comscore finds increased in-home data usage in U.S. amid global pandemic. Revieved from https://www.comscore.com/Insights/Press-Releases/2020/7/Comscore-Finds-Increased-In-Home-DataUsage-in-US-Amid-Global-Pandemic

Congressional Budget Office (CBO) (2020) Interim Economic Projections for 2020 and 2021., Washington, DC. https://www.cbo.gov/publication/56351

Corong E, Hertel TW, McDougall R, Tsigas ME, van der Mensbrugghe D (2017) The standard GTAP model, version 7. Journal for Global Economic Analysis 2(1):1-119

Chen J, Qi T, Liu L, Ling Y, Qian Z, Li T, Li F, Xu Q, Zhang Y, Xu S, Song Z, Zeng Y, Shen Y, Shi Y, Zhu T, Lu H (2020) Clinical progression of patients with COVID-19 in Shanghai, China. J Infect 80(5):e1-e6. https://doi.org/10.1016/j.jinf.2020.03.004

Christiano L (2017) The great recession: A macroeconomic earthquake federal reserve bank of Minneapolis. February 7. Accessed on October 9, 2020 at https://www.minneapolisfed.org/article/2017/the-greatrecession-a-macroeconomic-earthquake

del Rio-Chanona RM, Mealy P, Pichler A, Lafond F, and Farmer D (2020). Supply and demand shocks in the COVID-19 pandemic: an industry and occupation perspective. arXiv preprint. https://arxiv.org/abs/2004. 06759

Dey M, Frazis H, Loewenstein MA, Sun H (2020) Ability to work from home: evidence from two surveys and implications for the labor market in the COVID-19 pandemic. Monthly Labor Review, U.S. Bureau of Labor Statistics. June. Retrieved from:

Dingel J, Neiman B (2020) How many jobs can be done at home? Becker Friedman Institute for Economic at University of Chicago, White Paper. Retrieved from: https://urldefense.com/v3/_https://bfi.uchicago.edu/ wp-content/uploads/BFI_White-Paper_Dingel_Neiman_3.2020.pdf__;!!LIr3w8kk_Xxm!5 Pr8yUZjgGNcpsAZlotJJiA4ĀT_CufALAOpM-̄161latcf2jmJ-gFqasGDtZ23cY\$

Dixon P, Rimmer M, Lee B, Rose A et al (2010) Effects on the U.S. of an H1N1 epidemic: analysis with a quarterly CGE model. Journal of Homeland Security and Emergency Management 7(1):Article 7

Dixon P, Rimmer M, Giesecke J, King C, Waschik R (2020). The effects of COVID-19 on the U.S. macro economy, industries, regions and National Critical Functions. Report to the U. S. Department of Homeland Security Centre of Policy Studies, Victoria University, Melbourne, Australia.

Dormady N, Rose A, Roa-Henriquez A, Rosoff H (2019) Measuring business and economic resilience in disasters, final report to the Critical Infrastructure Resilience Institute (CIRI). University of Illinois, Urbana, IL

Hallegate, S. 2008. "An adaptive regional input-output model and its application to the assessment of the economic cost of Katrina," Risk Analysis 28 (3): 779-799.

Hertel TW, Tsigas ME (1997) Structure of GTAP. In: Hertel TW (ed) Global trade analysis: modeling and applications. Cambridge, New York, pp 13-73 
IMPLAN (2018) Impact Analysis for Planning (IMPLAN) System. IMPLAN, Huntersville

Intensive Care National Audit \& Research Centre (ICNARC) (2020) ICNARC report on COVID-19 in Critical care - 04 April 2020. Retrieved from https://www.icnarc.org/About/Latest-News/2020/04/04/Report-On2249-Patients-Critically-Ill-With-Covid-19

Mandel A, Veetil VP (2020) The economic cost of COVID lockdowns: an out-of-equilibrium Analysis. Available at SSRN 3588421. https://papers.ssrn.com/sol3/papers.cfm?abstract_id=3588421

Opportunity Insights (2020) Economic tracker. Retrieved from https://www.tracktherecovery.org/Opportunity Insights Economic Tracker. https://www.tracktherecovery.org/

OECD. (2020). Evaluating the Initial Impact of COVID-19 Containment Measures on Economic Activity." http:/www.oecd.org/coronavirus/policy-responses/evaluating-the-initial-impact-of-covid-19-containmentmeasures-on-economic-activity-b1f6b68b/

Prager, F., D. Wei, and A. Rose. 2017. "Total Economic Consequences of an Influenza Outbreak in the United States," Risk Analysis 37(1): 4-19.

Rose A (2017) Benefit-cost analysis of economic resilience actions. In: Cutter S (ed) Oxford research encyclopedia of natural hazard science. Oxford, New York

Rose A, Blomberg S (2010) Total economic impacts of a terrorist attack: insights from 9/11. Peace Economics, Peace Science, and Public Policy 16(1):Article 2

SafeGraph (2020) The impact of coronavirus (COVID-19) on foot traffic. Retrieved from: https://www. safegraph.com/dashboard/covid19-commercepatterns

Schrotenboer B (2020) Working at home had a positive effect on productivity during the pandemic, survey says, USA Today News. Retrieved from https://www.usatoday.com/story/money/2020/05/04/coronaviruspandemic-might-game-changer-working-home/3061862001/

U.S. Bureau of Labor Statistics (2019) Table 1. Workers who could work at home, did work at home, and were paid for work at home, by selected characteristics, averages for the period 2017-2018. https://www.bls.gov/ news.release/flex2.t01.htm

Unacast (2020) Retail impact scoreboard. Retrieved from: https://www.unacast.com/covid19/covid-19-retailimpact-scoreboard

Walmsley TL, Minor P (2020a) US trade actions against China: a supply chain perspective. Foreign Trade Review 55(3):337-371

Walmsley TL, Minor P (2020b) Demand shifts and willingness to pay in applied models. World Econ 43(6): 1499-1520

Walmsley TL, Minor P (2016) ImpactECON global supply chain model: documentation of model changes, Working Paper No. 06, ImpactECON, Boulder, CO. https://impactecon.com/resources/supply-chain-model/

Walmsley T, Rose A, Wei D. (2020) Impact on the U.S. macroeconomy of mandatory business closures in response to the COVID-19 pandemic. Applied Economics Letters, forthcoming.

Zandi, M., Kamins, A., Friedman, E., Sweet R., and Lafakis, C. (2017) The economic impact of hurricane harvey, moody's analytics, September 5. Accessed on October 8, 2020 at https://www.moodysanalytics. com/webinars-on-demand/2017/the-economic-impact-of-hurricane-harvey

Zhao W, Yu S, Zha X, Wang N, Pang Q, Li D, Li A (2020) Clinical characteristics and durations of hospitalized patients with COVID-19 in Beijing: a retrospective cohort study. medRxiv. https://doi.org/10.1101/2020.03. 13.20035436

\section{Data References}

ABC News/Ipsos Poll (2020a, May 1). Topline \& methodology [PDF File]. Retrieved from https://www.ipsos. $\mathrm{com} / \mathrm{sites} /$ default/files/ct/news/documents/2020-05/topline-abc-coronavirus-wave-7.pdf

ABC News/Ipsos Poll (2020b, March 20) Coronavirus outbreak triggering significant changes to American society [Press release]. Retrieved from https://www.ipsos.com/en-us/news-polls/abc-news-coronavirus-poll

ABC News/Ipsos Poll (2020c, May 8) Two in three Americans: opening country is not worth it [Press release]. Retrieved from https://www.ipsos.com/enus/news-polls/abc-news-coronavirus-poll

The Associated Press-NORC Center for Public Affairs Research (2020, March 19). Worries about the Coronavirus Increase [Blog post]. Retrieved from http://www.apnorc.org/projects/Pages/Worries-aboutthe-Coronavirus-Increase.aspx

Axios/Ipsos Poll (2020a, March 17) Axios/Ipsos Coronavirus Index March 18, 2020 [Press release]. Retrieved from https://www.ipsos.com/en-us/news-polls/axios-ipsos-coronavirus-index-03-18-2020

Axios/Ipsos Poll (2020b, May 5) Social distancing coming to an end? [Press Release]. https://www.ipsos.com/ en-us/news-polls/axios-ipsos-coronavirus-index

BEA (2019) Tourism satellite account. https://www.bea.gov/tourism-satellite-accounts-data-sheets 
BLS (2020) Civilian labor force participation rate. https:/www.bls.gov/charts/employment-situation/civilianlabor-force-participation-rate.htm.

CDC (2020a). Severe outcomes among patients with coronavirus disease 2019 (COVID-19) — United States, February 12-March 16, 2020. MMWR Morbidity and Mortality Weekly Report 69: 343-346. Retrieved from https://www.cdc.gov/mmwr/volumes/69/wr/mm6912e2.htm

CDC (2020b). Coronavirus disease 2019 in Children — United States, February 12-April 2, 2020. MMWR Morbidity and Mortality Weekly Report 69: 422-426. Retrieved from https://www.cdc.gov/mmwr/volumes/ $69 / \mathrm{wr} / \mathrm{mm} 6914 \mathrm{e} 4 . \mathrm{htm}$

CDC (2020c) Coronavirus disease - older adults. Centers for disease control and prevention coronavirus disease 2019. Retrieved from https:/www.cdc.gov/coronavirus/2019-ncov/need-extra-precautions/older-adults. html?CDC_AA_refVal=https\%3A\%2F\%2Fwww.cdc.gov\%2Fcoronavirus\%2F2019-ncov\%2Fspecificgroups $\% 2$ Fhigh-risk-complications $\% 2$ Folder-adults.html

CDC (2020d) COVID-19 forecasts. Centers for disease control and prevention coronavirus disease 2019. Retrieved from https:/www.cdc.gov/coronavirus/2019-ncov/covid-data/forecasting-us.html

CDC (2020e) Provisional death counts for coronavirus disease (COVID-19). https://data.cdc.gov/NCHS/ Provisional-COVID-19-Death-Counts-by-Sex-Age-and-S/9bhg-hcku/data. Accessed on 5/15/2020.

CDC (2020f) COVID19Surge v1.0 Manual. https://www.cdc.gov/coronavirus/2019-ncov/hcp/COVIDSurge. html

Chow N et al. (2020) Preliminary estimates of the prevalence of selected underlying health conditions among patients with coronavirus disease 2019 - United States, February 12-March 28, 2020 MMWR Morbidity and Mortality Weekly Report 69(13): 382-386. Retrieved from https://www.ncbi.nlm.nih.gov/pmc/articles/ PMC7119513/

Cohen M, Whittal K, Murray T (2020) COVID-19 cost scenario modeling. Wakely consulting group LLC. Retrieved from https:/www.ahip.org/wp-content/uploads/AHIP-COVID-19-Modeling.pdf

Cox C, Kamal R, McDermott D (2020) Health system tracker: how have healthcare utilization and spending changed so far during the coronavirus pandemic? Retrieved from https:/www.healthsystemtracker.org/ chart-collection/how-have-healthcare-utilization-and-spending-changed-so-far-during-the-coronaviruspandemic/\#item-start.

The Economist/YouGov (2020, May). Poll of 1500 US adult citizens. [PDF File]. Retrieved from https://docs. cdn.yougov.com/5yope37lqh/econTabReport.pdf

FAIR Health (2020) The projected economic impact of the COVID-19 pandemic on the US healthcare system. FAIR Health. Retrieved from https://s3.amazonaws.com/media2.fairhealth.org/brief/asset/COVID-19\% 20-\%20The $\% 20$ Projected $\% 20$ Economic $\% 20$ Impact $\% 20$ of $\% 20$ the $\% 20$ COVID-19\%20Pandemic $\% 20$ on $\%$ 20the\%20US\%20Healthcare\%20System.pdf

Gallup (2020, March 20) Americans rapidly answering the call to isolate, prepare [Blog post]. Retrieved from https://news.gallup.com/poll/297035/americans-rapidly-answering-call-isolate-prepare.aspx

Gold JA, Wong KK, Szablewski CM, et al. (2020) Characteristics and clinical outcomes of adult patients hospitalized with COVID-19 — Georgia, March 2020. MMWR Morb Mortal Wkly Rep 2020; 69:545-550. DOI: https://www.cdc.gov/mmwr/volumes/69/wr/mm6918e1.htm?s_cid=mm6918e1_w

Ipsos (2020, March) Tracking the Coronavirus: results from a multi-country poll. Retrieved from https://www. ipsos.com/sites/default/files/ct/news/documents/2020-03/tracking-the-coronavirus-wave-4-ipsos.pdf

Kaiser Family Foundation. (2020a, March 17). KFF Coronavirus Poll: March 2020 [Blog post]. Retrieved from https:/www.kff.org/global-health-policy/poll-finding/kff-coronavirus-poll-march-2020/

Kaiser Family Foundation. (2020b, April) KFF health tracking poll - late April 2020 [PDF File]. Retrieved from http://files.kff.org/attachment/Topline-KFFHealth-Tracking-Poll-Late-April-2020.pdf

Marketplace-Edison (2020, May 5). Marketplace survey wave nine [PDF File]. Retrieved from https://www. marketplace.org/wp-content/uploads/2020/05/Edison-poll-data-pt.-2.pdf

Morin, R. (2020, May 8). Americans more worried about reopening too quickly than not opening quickly enough, survey says. USA Today. Retrieved from https://www.usatoday.com/story/news/politics/2020/05/ 08/survey-most-americans-worried-country-reopen-too-quickly/5180069002/

National Alliance for Caregiving (2020) Caregiving in the U.S. 2020. https://www.caregiving.org/caregiving-inthe-us-2020/

NBC News/Wall Street Journal (2020, March). NBC News/wall street journal survey. Retrieved from https:/ www.documentcloud.org/documents/6810602-200149-NBCWSJ-March-Poll-Final-3-14-20-Release.html? utm_source=link_newsv9\&utm_campaign=item_296681\&utm_medium $=$ copy

New York City Department of Health and Mental Hygiene (2020) COVID-19 data. https://github.com/nychealth/ coronavirus-data/blob/master/by-age.csv. April 29, 2020.

NPR/PBS NewsHour/Marist Poll (2020, March 17). NPR/PBS newshour/marist poll results \& analysis [Blog post]. Retrieved from http://maristpoll.marist.edu/npr-pbs-newshour-marist-poll-results-analysis-13/ 
Reuters/Ipsos. (2020, March 17) Reuters/Ipsos poll: core political - coronavirus [press release]. Retrieved from https://fingfx.thomsonreuters.com/gfx/mkt/13/3563/3524/Topline\%20Reuters\%20Coronavirus\%2003\% 2017\%202020.pdf

Reuters/Ipsos Poll (2020, April 29) Reuters/Ipsos coronavirus impact on recreation [PDF File]. Retrieved from https:/www.ipsos.com/sites/default/files/ct/news/documents/2020-05/topline_reuters_coronavirus_tracker_ recreation_questions_04_29_2020_.pdf

SurveyUSA (2020, March 19) Results of SurveyUSA News Poll \#25248. Retrieved from http://www.surveyusa. com/client/PollReport.aspx?g=23b10fd3-4f50-43a0-b722-64b5a9fc143d

Trading Economics (2020) United States personal savings rate. Retrieved from: https://tradingeconomics.com/ united-states/personal-savings

U.S. Census Bureau (2019) America's families and living arrangements 2019: Table A1. Marital status of people 15 years and over, by age, sex, and personal earnings. https://www.census.gov/data/tables/2019/demo/ families/cps-2019.html

U.S. Census Bureau (2020a) Table 4. Families with own children: employment status of parents by age of youngest child and family type, 2018-2019 annual averages. https://www.bls.gov/news.release/famee.t04. htm

U.S. Census Bureau (2020b) National population by characteristics: 2010-2019. https://www.census.gov/data/ tables/time-series/demo/popest/2010s-national-detail.html

University of Southern California (USC) (2020, March 13) Bracing for coronavirus, U.S. residents are changing their behavior [Press release]. Retrieved from https://news.usc.edu/166834/coronavirus-survey-uscbehavior-changes-health-economic-fallout/

Voter Study Group (2020, May 13). COVID-19: tracking American perspectives. https:/www.voterstudygroup. org/covid-19-updates

Wikipedia (2020) COVID-19 pandemic lockdowns, https://en.wikipedia.org/wiki/COVID-19_pandemic lockdowns

World Bank (2020) Gross savings as percentage of GDP by Country. Retrieved from: https://data.worldbank.org/ indicator/NY.GNS.ICTR.ZS

Publisher's Note Springer Nature remains neutral with regard to jurisdictional claims in published maps and institutional affiliations.

\section{Affiliations}

\section{Terrie Walmsley ${ }^{1} \cdot$ Adam $^{\text {Rose }}{ }^{2} \cdot$ Dan Wei $^{3}$}

1 Department of Economics, Dornsife College of Letters, Arts and Sciences and Center for Risk and Economic Analysis of Terrorism Events (CREATE), University of Southern California (USC), Los Angeles, CA, USA

2 CREATE, Sol Price School of Public Policy, Schaeffer Center for Health Policy and Economics, USC, Los Angeles, CA, USA

3 CREATE, Sol Price School of Public Policy, USC, Los Angeles, CA, USA 